\title{
The ESCCB and the ACR: Is It the Same Fight? Reading on Others' Ideology: A Pragmatic Analysis of the CNN and BBC Websites
}

\author{
Yousreya Ahmed Ali Alhamshary \\ Department of English- Faculty of Education \\ Damanhour University- Egypt \\ alhamshary@edu.dmu.edu.eg
}

\begin{abstract}
Newspapers' websites, at hand every moment, communicating with people, play an essential role in expressing their thoughts, feelings, and needs. The language used by editors in news reports is very influential in attaining the communicative intent of such news reports, and they are constructed and manipulated to achieve specific purposes. The speech act is a part of pragmatics by which one knows what is meant beyond what is said. Thus, the present study investigates the types and functions of speech acts employed in $\mathrm{CNN}$ and $\mathrm{BBC}$ reports about both Egyptian and American events, namely, the blockade of the Supreme Constitutional Court (ESCCB) on December 2, 2012, and the American Capitol riot (ACR) on January 6,2021 , to find out if writers represent their social ideology in the coverage of both events. The present study applies John R. Searle's speech act theory as a framework to analyze the selected reports with a dataset of over 270,150 words on both sites about both events. Data is treated by MAXQDA software program. The results revealed that the writers of both sites are not biased against the case of the blockade and riot, but instead they are defending the stance of the law authority.
\end{abstract}

Keywords: Pragmatic Analysis, Speech Act, Ideology, MAXQDA, CNN, BBC.

\section{Introduction}

News as part of tackling world events has changed considerably throughout the last century. Social media opened a new field of technological progress of greater accessibility through online access to world news every moment. The increasing importance and ubiquitous news presence induced a field of linguistic research that occupies itself with the analysis of language in the news. In recent years, the internet as an easily reachable tool contributed to the many variations of news presentation, as it catalyzed the digital revolution to be a starting point for any change. Now, newspapers and networks further publish their 
news pages on the World Wide Web to be at everybody's hand at once. Reasons for that may be cost, time, efforts, and speed of reachability besides easiness of production for various types of news. The study will analyze the language used by $\mathrm{CNN}$ and $\mathrm{BBC}$ to present their news by scrutinizing their linguistic content in covering different sides of the political spectrum. This study performs a keyword analysis on a corpus consisting of texts, video files, and still images from the websites of both broadcasting networks as two major ones in the news field. The study tackles how readers may form information from details that may help construct and direct their attitudes or form their ideologies about specific topics.

Understanding any individual text begins by understanding its context, and the target of content analysis is to uncover the potential meaning produced by an individual text (Devereux, 2007). In the same context, Fairclough $(r \ldots r)$ asserts that content analysis seeks to understand the operations and ideology of any text that produces and reproduces the individual's ideology. Reah (1998) elaborates that mass media in their variable social context within which they are produced and received may make sense of and become incorporated into people's daily lives, forming their ideas and opinions, granting documentary discourse on all their activities. Media discourse focuses on its audiences from the different categories of society and the political discourse, as an essential part of the media discourse, not related to just the political participants. Hence, its principal authors' delimitation of political discourse is insufficient and needs to be extended to a more cumulative picture of all its relevant participants. Participants and actions in the political discourse are the core of such contexts and protest demonstrations as well. Again, text and context mutually define each other.

\section{Significance of the Study}

The study is significant in promoting a good understanding of the ideologies of the news published on the $\mathrm{BBC}$ and $\mathrm{CNN}$ on two important events in history. This research can benefit those pursuing their degree in language and linguistics because it provides background knowledge about how speech acts portray certain ideologies and power in directing public opinion. The study also provides new information to politicians, journalists, and mass media writers interested in the two events. The present research aims to identify the types of speech acts and describe the functions and roles of each type. The time, place, and context are critical for all the audiences and readers in both events and on both websites. The significance of this research lies in understanding how news websites' reporters can persuade 
The ESCCB and the ACR: Is It the Same Fight? Reading on Others' Ideology: A

Pragmatic Analysis of the CNN and BBC Websites

the reader to believe in or direct their behavior or be directed in another time and how the critical role of news can be a part of our daily lives.

\section{Statement of the Problem}

Media news and technology are used to distribute writers' ideologies and formulate the readers' knowledge about society. Two events have taken place and two websites wrote about them using certain words to affect the reader. A pragmatic analysis may reveal writers' ideologies and intentions behind what they produced to the readers about both events. The study is mainly concerned with speech acts employed and the illocutionary force or the ideologies that they represent. Linguistically, it should be proved that the American and British media and news writers especially in the two main networks -CNN and BBC- are not biased in reactions about basic beliefs and ideologies.

\section{Research Questions}

This research focuses on understanding how BBC and CNN represented the two events of the ACR and ESCCB on January 6, 2021, as protesters supported Trump, and January 1, 2011 (as a part of the famously known Arab Spring's continuous rapid events at that time), respectively. It is required that many questions are answered by this work. They are formulated as follows:

1- What types of speech acts occur in the language used in the networks' reports about both events?

2- What are the reasons for the occurrence of speech acts in the language used in the networks' reports about both events?

3- What language features are used to show the ideologies of CNN and $\mathrm{BBC}$ in their coverage of both events?

These three questions are answered to show the ideology of each website in dealing with two cases that may be similar in context but not similar in responses or treatment. It is supposed that the findings of this study will be useful for news writers, editors, and pragmatists.

\section{Review of literature and Theoretical Background}

Old papers' websites are essential as they contain snapshots from our lives and our culture that we need to form and represent our identity. For Reah (1998), news is defined as events of interest to a large group of people or those that may affect the lives of a sufficiently large group of people (p. 14). Thus, news is vital to people's lives as what they produce may be the cell for legislation later. During the Egyptian revolution, news played a significant role in transferring data that affected Egypt's destiny worldwide. However, as a receiver of this information, the reader has no control over what is presented in the news. At the same time, the 
editor is responsible for adding or omitting some of the real information that should be presented forming the readers' knowledge. According to van Dijk (1996), the mental models of our knowledge are constructed from the surrounding environment and the information one gets from their environment becomes knowledge later to be a part of their culture and habits in their life. Moreover, the quality of an individual's thinking depends on the models in their head. Accordingly, how people think and consequently behave depends on what they receive and how they receive it and construct their knowledge that leads finally to behavior which is a main target of spreading news. One of the functions of the press is to direct attitudes and beliefs. Newspapers, as a part of everyone's surroundings, are responsible for constructing most of this information inside individuals' minds and are called the fourth authority in society. The reader is not so negative to only receive but they should select and decide what to use to cumulatively build their background knowledge and swings in the information they are given to affect their future decisions in life. Therefore, only the reader's logic and the editor's honesty can be the real factors the lead the society in this area.

The Supreme Constitutional Court (SCC) of Egypt was founded under the authoritarian rule in 1971. It is an independent judicial body in Egypt, located in the Cairo suburb of Maadi. It is the highest judicial power in Egypt. It alone undertakes the judicial control in respect of the constitutionality of the laws and regulations and shall undertake the interpretation of the legislative texts in the manner prescribed by law. Its rulings are final and cannot be appealed in any way. However, this study is not to deal with any details about the constitutional court or any political events. The study is about a pragmatic analysis of two of the most famous news websites' pages, $\mathrm{CNN}$ and $\mathrm{BBC}$, during the periods of the blockade and Capitol riot to represent how they perceived the situation during those times. The blockade started on December 2, 2012, lasting for 18 days. Similarly, the recent Capitol riot in America started on January 6 in support of Donald Trump as the Brotherhood group did in support of Mohamed Morsi in December 2012. The United States Capitol is the seat of the Legislative Council of the United States of America. It is located in Washington, atop a hill called "Capitol Hill" on the eastern end of the National Mall National Park. Both events occurred at the end of the presidency of both presidents Morsi and Trump by their supporters and both events are considered unusual and have never happened in the history of both countries to break the law. 


\section{Social Media / News Network}

The term social media is used to refer to Internet-based sites and services that promote social interaction between participants. Examples of social media include (but are not limited to) discussion forums, blogs, wikis, podcasting, social network sites, content-sharing sites (like the video-sharing site YouTube and the photo-sharing site Flickr), and virtual worlds. Social media is often distinguished from forms of mass media, where mass media is presented as a oneto-many broadcasting mechanism (such as television, radio, or print newspapers). In contrast, social media delivers content via a network of participants where the content can be published by anyone but still distributed across potentially largescale audiences. CNN, an American cable news network, and BBC, a British cable news network, are chosen because of their extensive reporting on international news as well as their highest viewership ratings around the world. They run numerous international bureaus, which have been in operation since the networks were founded, situated in Abu Dhabi, Baghdad, Beijing, Cairo, Dubai, Istanbul, Jerusalem, Johannesburg, Lagos, London, Seoul, and Tokyo. Because they have affiliated reporters around the world, $\mathrm{CNN}$ and $\mathrm{BBC}$ can report on any event almost immediately.

For Reah (1998), the news is designed to evoke one particular response, thus establishing a set of shared values for a group of readers forming the target readers of the site, usually in opposition to another group who attack these values. Language always occurs within a context, and as social users of language, individuals know how to respond to linguistic triggers relating to the context of the language situation, the intended message, the feedback, and input from others. For Reah (1998), language is the key factor in the establishment and maintenance of social groups of society as an entity. The language of newspapers allows individuals to interpret the world and themselves; to express logic, cause, and outcomes; and to establish relationships within a group. Newspapers are not simply vehicles for delivering information. They present the reader with aspects of the news and present it often in a way that intends to guide the ideological stance of the reader. Their headlines are unique types of text that have a range of functions that specifically dictate its shapes, contents, and structures and, at the same time, restrict the writers' freedom.

\section{Pragmatics}

For Yule (1996.3), "pragmatics should consider aspects of context such as who people are talking to, when, where, and under what circumstances that will 
determine the way they say and what they want to say," whereas, for Leech (1983: 6), "pragmatics is the study of meaning which is related to the speech situations." Thus, pragmatics can be the study of the speaker's meaning where it involves the interpretation of what individuals mean in a particular context and how the context influences what is said. Consequently, pragmatics is the study of contextual meaning also that explores how a great deal of what is unsaid is recognized as part of what is communicated. Kempson (1986:251) defines pragmatics as "the study of the general cognitive principles involved in the retrieval of information from an utterance." In the same vein, Watson \& Hill (1993:146) describe it as "the study of language from the user's point of view, especially the choices, the constraints he meets with in employing the use of the language and the effects the use has on the communication situation." However, the pragmatic analysis "focuses on what a speaker might want the words to mean on a particular occasion" (Yule, 1996:114). Thus, meaning in pragmatics is defined relative to a speaker or user of the language (Leech, 1983:6). At the same time, Grice (1989) clearly defines pragmatics as "the study of how speakers and hearers interpret meaning in a particular context - taking account of the physical and social situation, knowledge of each other's background and cultural conventions..." and, therefore, pragmatics is the branch of linguistics dealing with language in use and the contexts in which it is used. The advantage of studying language via pragmatics is that one can talk about people's intended meanings, assumptions, purposes, or goals, as well as the kinds of actions they take and decide on their ideology.

A pragmatic analysis of the way some pieces of news are transmitted may elaborate a lot about the opinions and attitudes or ideologies of their writers as a representative part of their society. In this vein, pragmatic analysis of the two websites may represent the role of words in initiating and sustaining the intended meanings. According to Chiluwa (2007:70), pragmatic analysis plays a crucial role in websites reports because the pragmatic meanings are based on the writer's intentions. Language is a means of communication and presenting beliefs, but it is essential to know how it is used to shape ideas (Beard, 2000:18). The media and the forms in which they are shared by vast amounts of people and big groups show the social conditions of ideologies. Newspapers are also mainly oriented to producing information and entertainment, but concurrently, ideologies are expressed and questioned within them. Within newspapers, ideologies are evident in their choices of topics or opinion pieces. There are many differences between news networks that can be detected and reflect the reliance of each one in certain preferred forms of impression and their consistency of style over a long period 
within which ideologies can also be reflected. Scholars like Brewer (2009) assume that media framing of news coverage, especially with the rapid growth of technology that grants real-time reach to all events at any time and any place to the individuals, can mold the audience's opinions and beliefs about politics and ideologies, concerning both domestic and foreign issues in their lives. Some of the news networks' specific properties are the use of metaphors, images, symbols, keywords, and concepts which are repeated within news accounts and may codify a specific theme over time (Kuypers, 2002). Media framing rots the principles of a democratic society by positioning the individuals in a specific frame of mind and leaving them without the capability of making an autonomous decision. "Facts remain neutral until framed; thus, how the press frames an issue or event will affect public understanding of that issue or event" (Kuypers, 2002:7).

According to Song (2010, 876-877), context performs crucial functions that help interactants in interpreting utterances. These include removing ambiguity, specifying referents, and distinguishing conversational implicature. Physical and linguistic notions of context and intention are vital to pragmatics. As for intention, pragmatics assumes that success in the overall interpretation of an utterance involves a recognition of the speaker's intention. According to Sauerland \& Schumacher (2015:6), two notions of meaning need to be distinguished. The first is the speaker's meaning when producing a particular utterance. The second is the sentence meaning, or the semantic representation of the grammar allocated to a sentence. For Allott (2010:38), the context of an utterance signifies a source of information that assists the hearer in finding out what the speaker wishes to express. Without taking the context of words and phrases into consideration, it will not be likely to interpret the implicatures of an utterance. Moreover, in numerous situations, it will be impossible to calculate the proposition conveyed or the desired illocutionary force. Since pragmatics is interested in the speaker's meaning and how the hearer interprets it, context is vital to pragmatics. For Horn \& Kecskes (2013:262), discourse pragmatics is an attempt at widening the realm of pragmatics via emphasizing the importance of the social and cultural restrictions for interaction in addition to the linguistic and semantic properties of utterances. It aims at producing a sophisticated image of the functions and connectedness of pragmatics and discourse in the process of interactional and intercultural relation. Accordingly, there are two versions of discourse pragmatics: interactional and intercultural.

Language is most powerful when its role in presenting the world to an audience is not explicit; in other words, it is easy to resist a particular viewpoint 
or ideology when one knows it is being presented to oneself but not so easy to resist when the viewpoint or ideology is concealed. It is the role of pragmatics to reveal the implicit viewpoint to the reader and clarify the intended meaning of such cases. Language sometimes can be used to present groups to promote attitudes or conform to an existing stereotype. Language is one of how attitudes towards groups can be constructed, maintained, or challenged. Word choice plays a core role here. The patterns of word choice in a text carry a clear ideological message to the reader. Pragmatics here is used to denote the relationship between the sign and its user. The user is the one who acts. This aspect of language plays an important role when we consider the extent to which text can serve as an impetus or indeed as a commanding force for action. Language is never without a connection to action. The one who speaks does affect somebody else and wants to motivate them to take actions. Communication always has an aim (Mumby, 2009). Pragmatics cannot be dealt with without considering the context. Halliday (1985:5) states that context is events going on around when people speak and write. It entails a situation within which the communicative interaction takes place. Fromkin et al. (2003:593) explain: "Speech act is the action or intent that a speaker accomplishes when using language in context, the meaning of which is inferred by hearers." Pragmatics believes that what is communicated is more than what is said, and the speakers produce a more profound sense in communication than the actual meaning of the words or phrases they say.

Speech acts are acts that refer to the action performed by produced utterances. People can perform an action by saying something. Through speech acts, the speaker can convey physical action merely through words and phrases. Searle (1969) maintains that a speaker performs three kinds of acts in uttering a sentence. "Utterance acts are simply uttering strings of words." Instead, propositions are always "expressed in the performance of an illocutionary act" (Searle, 1969:29), and from this he can distinguish two syntactic elements in a sentence, a "propositional indicator" and an "illocutionary force indicator" which indicates "what illocutionary act, or function, the speaker is performing in the utterance" (Searle, 1969:30). Upon the recognition of the illocutionary force of utterances, Searle (1976) modified his classification as follows: 1) assertives where speakers are committed to the truth of some proposition, e.g., stating, claiming, reporting, and announcing, 2) directives that count as an attempt to bring about some effect through the action of the hearer attempts by the speaker to get the addressee to do something such as questioning, commanding, suggesting, requesting, ordering, demanding, and begging, 3) expressives that count as the 
expression of some psychological state or an expression of a psychological state, e.g., thanking, apologizing, welcoming, and congratulating, 4) commissives where the speakers are committed to some future action or the speaker is committed to some future course of action such as promising, threatening, offering, and swearing, and, finally, 5) declarations in which speech acts with successful performance bring about the correspondence between the propositional content and reality or affect immediate changes in the institutional situation and which tend to rely on elaborate extralinguistic institutions, for example, excommunicating, declaring war, christening, firing from employment, naming a baby/ship, resigning, dismissing, and accepting.

\section{Ideology}

"Ideology" is defined by Calzada-Perez (2003) as being linked with the concepts of power relations and domination and if persons assume those beliefs, even where they call themselves aesthetic, religious, or poetic, to be political in the sense that their application establishes a relation of dominance. As ideology is a coherent set of ideas, it often appears as fragmented meanings of common sense located intertextually in a variety of behaviors. Billig et al. (1988) distinguish what is called "lived" from "intellectual" ideologies; as a "lived" ideology is a complex, contradictory, and constitutive part of the meaningful practices of daily life, "intellectual" ideology is a coherent system of thought: philosophical orientations and political and religious codifications. However, ideology can be presented as a coherent set of ideas; it often appears as fragmented meanings of common sense located intertextually in a variety of behaviors. Accordingly, ideology can be constructed as beliefs and attitudes through the received language. At the same time, it can be represented through the language used in communication with readers to direct their thoughts and opinions. For Carvalho (2000, p. 26), ideology as an inherent part of texts significantly influences the patterns underlying the way individuals formulate their text and its meaning. It shapes "the selection and representation of objects, actors, the language, and the discursive strategies employed in a text. However, one should expect the ideological standpoints of writers not to be explicit in the text. To identify them it often requires a good deal of interpretive work." Fairclough (1995, p. 14) maintains that “... ideologies are propositions that generally figure as implicit assumptions in texts, which contribute to producing or reproducing, unequal relations of power, relations of domination." Moreover, ideology is linked to the reproduction of power. The headlines and the paragraphs in the selected reports or video files highlight the central role of social media in the concept of revolution and in political 
transformation in both countries. This is meant to influence mental and social models in a way to encourage certain interpretations.

Discourse structure is likely to influence the formation of mental models and social representations (van Dijk, 1998). The relationship between language and ideology has attracted many studies like Fowler (1979), van Dijk (1997), and Fairclough (1995). The results of their studies have shown that news does not give the audience the facts about the reported events. Fowler (1979), van Dijk (1997), and Fairclough (1995) demonstrate that news is exposed to amendment, alteration, and manipulations for the purpose of serving the ideology of the news writers and framing the ones of the readers or viewers. In addition, they demonstrate that the news depends on the recipients' (audience) awareness and background and the purpose of targeting them. Many studies are conducted on media and news with different targets like Barkho (2008) on the social power of the news discourse where textual analysis of the news output of Aljazeera English and Arabic is used in comparison and parallel with the BBC and CNN. Barkho (2007) examines the relationship between the language of the writers and the differences in the news coverage of events with a focus on investigating each of AJE, CNN, and BBC's news coverage of the Palestinian-Israeli conflict. The study of Wenden (2005) examines the role that language plays in social life, particularly the political struggle, whereas Javed and Mahmoud (2011) focus on the news headlines of Pakistani newspapers. Ghannam (2011) also examines the relationship between language and ideology. All these studies have shown different results about the effects and relationships between language and ideology. The reviewed literature about discourse and the media in various countries provided sufficient information on how news writers manipulate their writing to serve their ideologies.

In general, knowledge or language is transmitted through social context and relations defined in the value system and ideologies of culture. That is why we cannot decide what comes first: constructing the ideology or transmitting knowledge to construct it. It seems as if they have an interactive relation. One cannot decide if the audience have the background that lets them get a certain idea, if the language transmitted to them directs their opinion through constructing their ideas, or if the writers are writing language that agrees with their backgrounds. However, their responses represent what they are really in their mental constructions that are a product of all the elements, language, text, and context. Text and context are aspects of the same process; is it text interpreted according to context or context that forms the text and so forth? The kind of language used in the situations of both events cannot be understood unless one understands what 
is going on and unless one has some videos of what is happening at the same time. In both cases, readers should understand the whole background also to get the meaning of what is written and interpret the practices of individuals in the situation or context and get the meaning of what is written at the same time. Therefore, what is written is an output from a mentality with specific knowledge and at the same time input to another mentality with or without the same knowledge and both are interactive with each other in the same context. In this way, sentences written by or said by newspapers or mass media are considered a dialogue between those who produce and those who receive it and affect the responses of both. Fowler (1991:4) points out that differences in expression stem from ideological distinctions and evaluates the issue from a theoretical point of view emphasizing that "each particular form of linguistic expression in a text has its reason." He adds that there are always different ways of saying the same thing, and they are not random, accidental alternatives. For him, differences in expression carry ideological distinctions and thus differences in representations or interpretation. He argues in favor of adopting a linguistic approach in understanding the language of newspapers since nearly all meanings are socially constructed. This elaborates how the language of news and mass media is critical and not only transmits but also has an embedded message that should be understood in the light of linguistic view and one should be aware of the way they can interpret them correctly.

The role of pragmatics can emerge in revealing the real intentions of the text producer which are sometimes obscured and, thus, lead to a sense of misunderstanding on the part of the text producer (van Dijk, 1977:216). Pragmatics is viewed as an act of communication that affects all fields of life. Mey (2001:6) puts it in this way: "Pragmatics as the study of the way human being use their language in communication, bases itself on a study of those premises and determine how they effect and effectualize human language use." It is well known that the use of speech acts is part of the activities of human communication. Identifying the type of speech acts used can help the listener or reader infer something that is not expressed by the speaker explicitly. Fromkin et al. (3003:593) explain that

Speech act is the action or intent that a speaker accomplishes when using language in context, the meaning of which is inferred by hearers. (Example, there is a bear behind you) may be intended as a warning in certain context or may in other context merely be statement of fact.

Basically, ideologies are foundational social beliefs of a rather general and abstract nature. Thus, just as there are no private languages, there are no private, personal ideologies. Hence these belief systems are socially shared by the 
members of a collectivity of social actors. One of the cognitive functions of ideologies is to provide (ideological) coherence to the beliefs of a group and thus facilitate their acquisition and use in everyday situations. Ideologies also specify what general cultural values such as freedom, equality, and justice are relevant for the group. Sometimes, ideologies become shared so widely that they seem to have become part of the generally accepted attitudes of an entire community, as obvious beliefs or opinions, or common sense. During all historical events, America adopted the democracy aspect and exported to the whole world that it is the source of democracy and freedom in addition to respect of the law and modern life with decent behavior. That is maybe one of the reasons for the shocking response to the rioters' activity.

Basically, and from a cognitive point of view, the memory processes involved in the understanding, representation, and retrieval of events' news are dealt with by both journalists who gather and write news and the readers who reconstruct events' news in the form of knowledge and beliefs by updating processes all the time with the news updating as well. This allows individuals to form an explicit and well-known role of news values and ideologies in the production and understanding of news (van Dijk, 1988). Thus, ideologies through news networks organize and ground the social representations shared by the members of (ideological) groups. Secondly, they are the ultimate basis of the discourses and other social practices of the members of social groups as group members. Thirdly, they allow members to organize and coordinate their actions and interactions in view of the goals and interests of the group as a whole. Finally, they function as the part of the socio-cognitive interface between social structures of groups on the one hand and their discourses and other social practices on the other hand. Some ideologies may thus function to legitimize domination but also to articulate resistance in relationships of power. Other ideologies function as the basis of the "guidelines of professional behavior." Ideologies are not "known" by all of their members. The rioters already share the American beliefs and social attitude. Not all members identify with an ideological group in the same way and equally strongly. This suggests that individuals may be "more or less" members of ideological groups. Ideologies provide people with rules of practical conduct and moral behavior and are thus equivalent "to a religion understood in the sense of a unity of faith between a conception of the world and a corresponding norm of conduct." The term ideology is understood here as the social (general and abstract) representations shared by members of a group and used by them to accomplish everyday social practices: acting and communicating (Fowler, 1991; van Dijk, 
The ESCCB and the ACR: Is It the Same Fight? Reading on Others' Ideology: A

Pragmatic Analysis of the CNN and BBC Websites

2007). How the discursive practice process functions in a newspaper can be illustrated in the following flowchart:

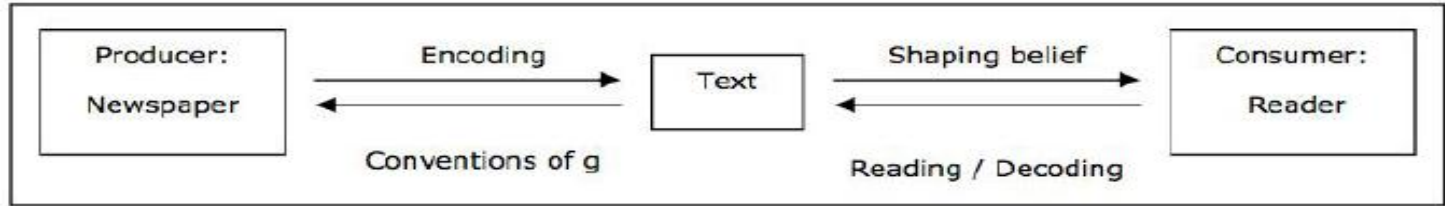

Fig 1: How the discursive practice process functions in a newspaper, Richardson, 2007, p. 39

The diagram illustrates the dynamic relationship between the production of texts and the consumption of texts, displaying the encoding and decoding process. To have the correct interpretation between the producer or writer and reader, there should be a shared background and understanding of the discourse for both events. Similarly, the text shapes the reader's belief, but at the same time, the consumer decodes the text. Decoding is not a simple, straightforward process as readers have their perspectives, background knowledge, agendas, and so forth. These elements "can (and mostly do) differ from the producer's ideas and knowledge." Readers also have their opinion and background about the producer, which may influence the decoding process (Richardson, 2007, p. 41). Production and consumption of discourse require the activation of shared mental representations to achieve the highest level of communication. Meaning construction depends on how close or far the mental representations are between the producer of the discourse and its receiver. Discourse production requires the speakers or writers' awareness of surrounding functions that are associated with the social, historical, and cultural context of the discourse to make themselves understood, and the interpreter of the discourse, whether listener or reader, employs the same functions to make sense of and construct meaning from the discourse; a mismatch in social representations yields communication breakdown. Hall (1980:54) argues that the meanings achieved through the processes of encoding and decoding depend on the degree of "asymmetry between the codes of the 'source' and the 'receiver' at the moment of transfiguration into and out of the discursive form." Presuppositions are what encoders treat as common ground and are known by decoders. In making presuppositions, a speaker/writer asserts the content of the utterance and considers it unchallenged and taken for granted. Wodak (2007:214) argues that "presupposed content is, under ordinary circumstances, and unless there is a cautious interpretive attitude on the part of the hearer, accepted without (much) critical attention (whereas the asserted content and evident implicatures are normally subject to some level of evaluation)." Therefore, an analysis of 
presuppositions reveals encoders' beliefs as well as what they want their recipients to take as a given. Fairclough (2003) distinguishes between three types of presuppositions, or what he calls assumptions: existential, propositional, and value-laden. Existential assumptions are about what exists, propositional assumptions are about what will happen, and value-laden assumptions are about what is considered right or good. Ideological presuppositions are value-laden as they make judgments and express values.

Most previous studies of the language used in media concentrate on the stylistic and rhetorical aspects of those that are employed in newspapers, especially those related to headlines like Muhammed (2005), Siposova (2011), Abba \& Nasiru (2015), Prakash \& Dhawan (2017), and Roya \& Mahadi (2017). A study by Rustam (2013) was conducted to identify the illocutionary acts included in the CNN news channel headlines representing Pakistan. Many studies were carried out to illustrate the idea of the relevance and effect of the language used and ideologies, attitudes, and how press or internet broadcasting can affect the individuals or be affected by them. In a study by Glover (2011), he specifically focused on the portrayal of the Muslim Brotherhood by CNN and the Fox News channel and analyzed their content in television broadcast transcripts. His analysis aimed to provide a holistic review of the scope of the coverage and discrepancies in reporting during the crisis in addition to examining the American understanding through the popular news media on an Islamist political group in the forefront of the political upheaval presently occurring in Egypt. His study illuminated a bias in both news channels and showed a higher frequency of exaggerated extremism in the reporting of the Fox News channel.

Another study by Novianto (2015) investigates some selected news reporting the Syrian conflict on CNN and Aljazeera in May 2014. It utilizes a descriptive qualitative method that comprehensively focused on the description of rhetorical patterns and the writer's strategies in convincing the readers. Findings show that there is a preferred rhetorical pattern in each news website. Two rhetorical patterns are found: English and Semitic. Another finding of the study shows that both news websites applied three appeals of convincing readers. The difference was found in the strategy of applying those appeals. Hence, each news website has its way of applying those three rhetorical appeals.

By the same token, Yuwartik \& Nurhayati (2016) conducted a study about the types of illocutionary acts she found in the dialogues of The Black Cat novel and the impact of a perlocutionary act in the dialogue uses of The Black Cat novel. She used library study based on its purpose. She collected data by documentation. 
She used Searle's theory to analyze the illocutionary act and perlocutionary act. The findings showed that both the illocutionary act and perlocutionary act are found in the dialogue between the characters. The found illocutionary acts are (1) the assertive act including informing, stating, claiming, reporting, and suggesting, (2) the directive act including requesting, refusing, commanding, warning, and ordering, (3) the commissive act including offering and promising, (4) the expressive act including apologizing, praising, thanking, welcoming, refusing, and blaming, and (5) the declarative act including declaring. The dominant is the assertive and commissive acts. This study helped the researcher to gain more understanding about illocutionary, especially representative, acts.

Ilyas \& Khushi (2012) in their study while exploring communicative functions of Facebook status updates using Searle's speech act framework indicate that the status messages are frequently constructed with expressive acts, followed by assertive and directive acts. As for the communicative functions, their findings reveal the emergence of various socialization patterns through the sharing of feelings, information, and ideas. Likewise, Tauchid \& Rukmini (2016), by examining the performance of expressive speech acts on Wayne Rooney's Facebook page, indicate that expressive speech acts of congratulating tended to cause the hearers to respond in the same way as what the speaker intended, namely, congratulating; meanwhile, expressive speech acts of complimenting, thanking, and boasting were likely to cause the hearer to produce many compliments as responses. By the same token, Mahammad et al.'s (2018) study of speech acts in the Facebook updates posted by an apostate indicates that the expressive speech act is the most frequent act (33\%), followed by the directive (27\%), assertive (22\%), and commissive (18\%) acts, respectively. Because of the application of Searle's perception of speech acts, all these studies were commonly unable to investigate and clarify the perlocutionary effects of Facebook comments. According to Yule (1996:3), there are four areas with which pragmatics is concerned:

(1) Pragmatics studying the speaker' meaning. Consequently, it has more to do with the analysis of what people mean by their utterances than what the words or phrases in those utterances might mean by themselves.

(2) Pragmatics studying the contextual meaning. It involves the interpretation of what people mean in a particular context and how the context influences what is said.

(3) Pragmatics studying what is communicated than what is said. It explores how listeners can make inferences about what is said to arrive at an interpretation 
of the speaker's intended meaning. It also explores how much of what is unsaid is recognized as part of what is communicated.

(4) Pragmatics is the study of the expression of relative distance. Depending on how close or distant the listener is, speakers determine how much needs to be said.

Thus, pragmatics is viewed as the study of language use in particular communicative contexts or situations of necessity. It would make use of the knowledge of the message being communicated or the speech act being performed, the participants involved, their intention and knowledge of the world and the impact of these on their interactions, what they have taken for granted as part of the context, the deductions they make on the basis of the context, what is implied by what is said or left unsaid, and so forth (Leech, 1983, p. 20; Watson \& Hill, 1993, p. 146). All the previous four areas are of great importance when analyzing the selected data. From a cognitive point of view, we deal with the memory processes involved in the understanding, representation, and retrieval of news events by the journalist in news gathering and writing and by the reader in processes of reconstructing news events in knowledge and belief updating. This allows us to make explicit the well-known role of news values and ideologies in the production and understanding of news. Cultural resources are basics of forming identities. Consequently, all identities need a shared past to decide who belongs to where and when. Language is used to represent the reality of context. Things or words have no meaning outside their context, which is formed in two types: cultural context and situational context. Text or spoken production of knowledge is based on mental models of an individual's experience or events. At the same time, these models are shaped by the existing knowledge and more or less are shared with general attitudes and ideologies. Mental models in the form of beliefs allow us to link personal ideas and attitudes with the outside social discourse. We can relate discourse to certain societies only through the behaviors of its participants. What technology and especially news networks have done is open cultures to be shared with all who can reach them. However, ideological borders relate values to those who can keep them.

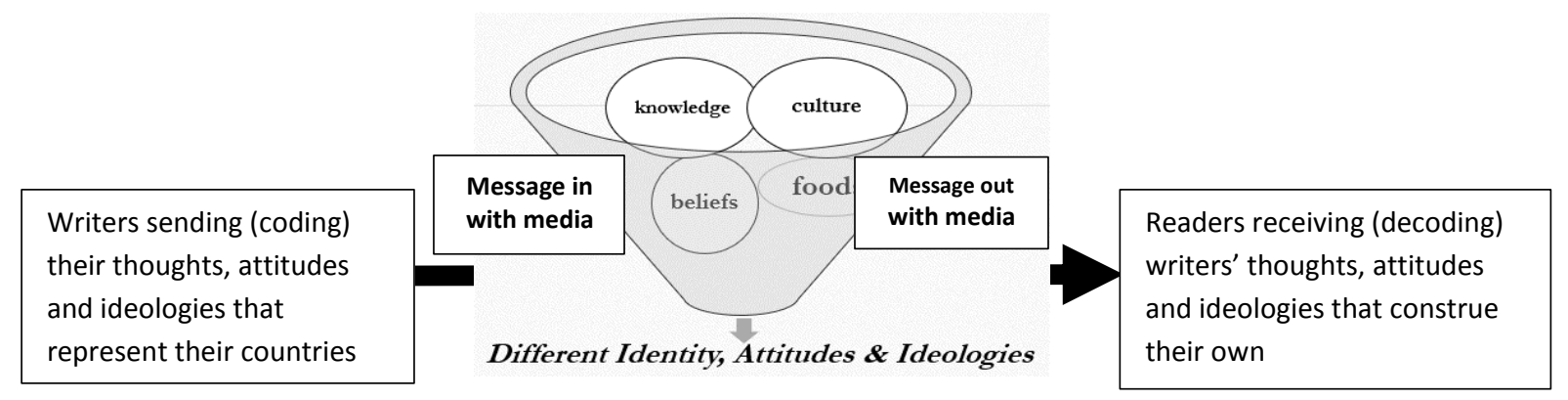


Fig 2: How writers use the code model of communication.

The media plays here the role of the speaker, and the receiving reader or hearer is the hearer who decodes the message sent by the media producers. From the above, how media help in constructing mental knowledge of the readers can be seen and can, by no means, direct them to believe or behave in a certain way. Halliday \& Hasan (1970) views language as a means of organizing people and directing their behavior through the words used. The present study is trying to find out if the media of both networks have a role in directing the minds in both events and how the writers were a tool to spread certain ideologies during both events. The language used in the reports will be analyzed to find out the ideologies of the writers in both networks in dealing with both events.

\section{Methodology}

The aim of this study is to investigate how the two newspapers' websites with different and sometimes opposing ideologies used language differently when reporting and interpreting the same event. A speech act is premised on the fact that people perform various actions using words, and when utterances are made, a particular act is performed. It also seeks to examine if, and to what extent, the ideology behind the text affects the expression of the newspaper in question. The aim is not to evaluate the quality of the newspaper reporting but to investigate how language is used to express the ideology of each newspaper by its writers who represent their society. Firstly, the content is manually downloaded by copying and pasting the body of the selected articles from the website into text files. This did not include any other part of the website, for example, links to other articles, navigation panels, or tweets or comments about the articles that were embedded in each article. The entire content of the article is analyzed, namely, headlines and texts. This study may not be the first academic study to analyze the ideology of newspapers in relation to the language used and the way in which language is employed, but it is the first in relation to both events highlighted. The study takes Searle's speech act framework as the primary approach to the data analysis. The research data was collected from both sites for a month during the period from December 29, 2011, to January 28, 2012, for the first event, ESCCB, and from January 6, 2021, to January 6, 2021, for the second event: the ACR.

What is interesting about the press is its role in the democratization of societies and documenting that for everyone to have. These two media broadcasters are chosen for their popularity and accordingly their ability to 
influence the masses. According to Media Newsline, it is estimated that BBC and $\mathrm{CNN}$ are "the largest broadcaster in the world by number of employees, facilities and followers." They are both considered worldwide trusted media explainers. Both events are also selected due to the resemblance between them as two presidents with supporters defending them illegally and the fact that both events had never happened before and because both countries have been recently experiencing social-political change. The selected speeches vary in length and number of sentences. Efforts were made to calculate the percentages of the speech act types so as to make the interpretation of the tables clear and empirical. The calculation of the percentages of the speech acts in a speech is based on the number of sentences and not on the total number of speech acts in each written report.

The pragmatic analysis is supported by a statistical analysis to quantitatively answer the questions of the study. This work limits itself to the analysis of the linguistic form and meaning that can be found in the reports covering the events in the decided time. The analysis of the data under scrutiny is of two types: qualitative (pragmatic) and quantitative (statistical). The former is done by means of the analytical framework discussed above. It aims at revealing what kind of speech acts is exploited on the news sites. The latter is intended to statistically support the findings of the former analysis and answer the study questions. The research uses the pragmatic analysis approach by Searle because it can uncover the attitudes and ideologies of the writers and presenters of both events through the embedded meaning of language use "to explain the relationship between language, ideology and power" (Janks, 1998). The study examines 75 news articles published by $\mathrm{BBC}$ and $\mathrm{CNN}$, as will be presented in the following part. An analytical description about the reports of BBC and CNN depended on constituting their portrayal of the events to the readers or viewers on their websites.

\section{Data Collection}

What is written about ESCCB in the press is very little, maybe because there were many events at that time related to the whole Arab area, not only Egypt. However, there is much written about ACR. Most of the raw data related to this topic is video records, and few text titles are published on both websites. The critical point about online networks is that these articles are published in online international newspapers, given the global nature of the Arab Spring event, written about the topic from different perspectives, depending on the journalists' or reporters' background and ideological belonging and news media organization. 
They are based on different contexts (e.g., social, cultural, political, religious, and historical and a combination of these), which means that what constructed the information and knowledge about reality is what is seen directly and what is predicted through the receivers'/viewers' or readers' background. At the same time, they are documented for the history of that era without any control apart from only the owners and the readers or viewers. The research procedures are as follows:

1. Data is collected: mapping up numberless articles published online by the $\mathrm{BBC}$ and CNN media networks on their websites.

2. Then, the dataset is refined according to whether the articles are relevant to the events or not.

3. The dataset is categorized and is limited to text for applying the theoretical frameworks.

4. Data is treated by the program to get statistical categorization of speech act types.

5. Grouping the utterances in relation to the types of illocutionary acts.

6. Statistical results are interpreted and discussed with reference to some quoted sentences.

7. Final findings are gathered and summarized.

The primary data for this study are selected reports collected from CNN's official website from January 6 to 7, 2021. The main news pages are downloaded. The data were collected from online news sources, including the CNN website (www.cnn.com) and the BBC website (www.bbc.com). After copying the data from web pages, unnecessary were neglected. Then, the selected data were treated. Both quantitative and qualitative analyses of the documents were obtained from the program allowing for contextualization of the coded words and phrases indicative of framing measurements, and even moral judgments, which are present in the narrative. Other sources were video files and pictures attached with the titles and they were treated with the same program. The raw data analyzed can be represented in Table 1 .

Table 1B: Number of raw data sources used in ESCCB.

Table 1A: Number of raw data sources used in CR.

\begin{tabular}{|c|c|c|c|}
\hline$\underbrace{\text { Network }}_{\text {Source }}$ & BBC & CNN & Total \\
\hline $\begin{array}{l}\text { Written } \\
\text { Report }\end{array}$ & 5 & 51 & 56 \\
\hline
\end{tabular}

\begin{tabular}{|l|c|c|c|}
\hline Network & BBC & CNN & Total \\
\hline $\begin{array}{l}\text { Written } \\
\text { Report }\end{array}$ & 1 & 3 & 4 \\
\hline
\end{tabular}

As seen from the tables, there is much raw data concerning the Capitol riot and very rare data related to the ESCCB. This may be due to many reasons. First, 
the ESCCB occurred during the period of the Arab Spring where there were numerous events that should be covered, which meant the event only appeared as an announcement in the news bar and there was not enough attention to cover it. Secondly, the occurrence of a ACR is rare in a country like America where they lead the world in democracy and modern liberty organized by law, and what happened there was a shock to the whole world, not only the Americans. Therefore, the scope of the study is limited to the analysis of written reports by using the MAXQDA program to attain data about the speech act elements used on the two international news websites, namely, BBC and CNN. By contrasting and comparing the use and function of speech act elements in the news websites of $\mathrm{BBC}$ and $\mathrm{CNN}$, it is anticipated that, due to divergence in ideology and political position, inconsistencies and differences can be found with respect to the use of speech acts.

\section{Data Analysis and Discussion}

The ways in which language is used are the main concern of the speech act theory where speech acts are identifiable as language units. Consequently, language as a powerful weapon in getting to the individuals' thoughts and ideologies is a link between social media and social change where there is a general recognition that social media have implications for social change. Social media are increasingly becoming an instrumental approach to, and power for, social change as what happened during the period from 2011 to 2020. News networks increased this social change and played a core role in identifying new social identities and ideologies for everyone globally, giving rise to a new discourse. It is pertinent to state that the speech acts could be intended or unintended, as the speaker is often unaware of some speech acts' tactics, especially the indirect illocutionary acts. News networks endeavor to identify the full range of inferences that a hearer or a reader would make when encountering the locutions of a writer or a speaker, considered in context. The analysis of the news articles is divided into two parts. The first part focuses on the BBC network dealing with both events and the second part deals with $\mathrm{CNN}$ also dealing with both events.

\section{BBC Network}

$\mathrm{BBC}$ reports are rare about both events, as explained above. The analysis part is very rich with examples; however, the researcher limits examples for illustration only. The total number of examples is presented in numbers in the 
Results part. When dealing with the first speech act, commissive, this is seen in many examples like "The victory marks the first time the Democrats will have been in control of the Senate" which indicates that they would have the responsibility going forward to control the situation after Trump. Another example is "president-elect Joe Biden will be able to push forward with his plans as a President, such improving America's commitment to climate change" which indicates that the writer is supporting Biden using the noun "victory" to indicate that he is against Trump likening election as a real battle where Americans won and is giving a future commissive act that Biden is going to change America. Another example is "After the Capitol building was secured, lawmakers returned to the Senate to finish counting the electoral votes to confirm Biden's victory" which is a commitment that everything would be all right and would be as usual. This means that what happened will not affect Biden's having his control over America and that Trump's period is over. The illocutionary force is boosting the intention of the Americans to get America to the right stable condition.

The second type of speech act represented in the analysis is declaratives. Examples of sentences including such type of acts are many, for example, "Lawmakers met on Wednesday to count electoral votes to confirm Joe Biden's victory in the presidential election" where the writer is emphasizing victory by no means that Biden becomes the president. Another example is "The shift of political power in Congress marks another loss for the Republican party whose current leader Donald Trump has continued to make claims that the election result last year was false because of fraud. However, there is no evidence that his claims are true." Here, the writer uses a statement that can play as stating the actual condition of America and reporting about Trump's status. It can also be used as a declarative act indicated by the word the "shift of political power" as an indication of Trump losing power and Biden gaining it. It can also be used for expressing the writer's rejection of Trump and that they are accusing him of not being honest. Therefore, he is directing Trump's followers not to believe him since this was not the first time, he made such claims. The word "claims" is indicative. Donald Trump continued to make claims that the election result last year was false because of fraud. However, there was no evidence that his claims were true. The writer expresses their untrust in Trump's claims. In the example "We had an election that was stolen from us. It was a landslide election, and everyone knows it, especially the other side," this is a clear confession that at the time Trump was not the president of the USA and he is asking the Americans to restore his position. "But you have to go home now. We have to have peace." Here Trump was 
The ESCCB and the ACR: Is It the Same Fight? Reading on Others' Ideology: A

Pragmatic Analysis of the CNN and BBC Websites

directing his followers to go home in order to get peace back. The use of the pronoun "us" represents that Trump was joining the Americans and by no means he is out of being conscious. He was asking the Americans to join him and support him to restore the elections. The sentence "The Federal Bureau of Investigation (FBI) has also put out an appeal for help in identifying people who actively took part in the violence that happened in the Capitol building and surrounding areas on Wednesday" is declaring that there is a law and that what happened was wrong and those who took part in it would be punished. This is a hidden threat that protesters shout should have stopped as there was a future punishment for them. The sentence "a member of the Oath Keepers militia group, pleaded guilty to two charges - obstruction of an official proceeding and entering a restricted building with a dangerous weapon" means that Schaffer was going to be arrested and may be imprisoned for committing crimes. There is also a directive attitude to stop the event and to feel secure as it was over. Future procedures are going to take place and people will be arrested as well.

Headlines also play a role and contain a lot like "America suffered an unprecedented attack on its democracy yesterday. We want to hear from you." This is a directive and expressive speech act at the same time. The writer is expressing their impressive attitude that this action is strange and is not common in their society using the word "unprecedented "that boosts the refusal of the action itself and at the same time asks people to provide what they know about the event. The expression "We want to hear from you" directing the reader or hearer to help them also means that it is asking them if they have any proof or evidence to send it. This act boosts the responsibility feeling towards their nation and their society. This illocutionary hidden force identifies their ideology and beliefs. Another headline shows friendliness and peace as a video appears to show a Capitol Hill police officer taking a selfie with a rioter. This contextual situation provides a rapport feeling which is indication of love and friendliness that fosters unity and peace. Biden expressed sorriness and pain over the event, and this is reflected in one of the striking headlines using the adjective phrase "darkest days in the history of our nation." However, "Washington DC riots: What happened?" is an attractive title to motivate people to know what happened and at the same time correct any misconceptions as an official declaration of what really happened. The writer is setting up mental knowledge for the readers. In a sentence like "Thousands of protesters gathered outside the Capitol building" the writer is expressing the unusual status of the protesters and that they could not be controlled 
by the security thus, giving an excuse for any unsecured attacks of the protesters and any violence that could have happened from this massive number of people.

Directives are somehow used more. A sentence like "Lots of people mainly those in support of Trump - aren't happy that Biden got into power" is used to boost rejection of Trump's continuity and consider him the source of the problem. In "President Trump had spoken to thousands of his supporters in Washington DC on Wednesday, urging them to march to the Capitol to protest the election result" the writer emphasizes that Trump was the source of the problem as he spoke to his supporters and directed them to do what they did. The writer is fostering the reader to believe that Trump was responsible for what happened. Then the writer used "To storm the Capitol, to smash windows, to occupy offices on the floor of the United States Senate, rummaging through desks, on the House of Representatives, threatening the safety of duly elected officials. It's not protest; it's insurrection" to show how violent the rioters are, expressing anger and indignation and criticizing the rioters' deeds. All adjectives and nouns used represent violence and rejection of the American democratic principles. Here, Biden accused Trump of insurrection to represent that he does not follow the American society's rules and he could not be responsible for it. The adjectives used in the text express terrorism, not democracy. The writer then used "He posted a video on Twitter where he told those who took part in the riots to go leave the premises and go home. However, he's continued to make claims that election fraud took place." The writer is trying to deny what Biden said about him and represent that he is against violence and he is confessing that what happened was wrong and should have ended. In the sentence "Donald Trump has been suspended from Twitter and Facebook after tweeting to supporters who attacked the US Capitol" there is a clear expression to stop as even the former president was prevented from doing the usual activities because he made a mistake. The writer is directing people to respect the country and never do any such thing again. In "This shows Trump's feeling that he was trying to make himself look good by telling his followers to invade the White House privately and then posting videos saying 'Leave the premises immediately' and he was only saying the election was rigged because he didn't win! He must be mad" the writer presents Trump's status after what he had done reporting on the event. The writer in the sentence "He repeated unfounded claims that the election was stolen from him, and told those gathered: "If you don't fight like hell, you're not going to have a country anymore" shows that Trump asked his supporters to go directly to the Capitol and break the law thinking that this violence may restore his presidency. Another example of a 
The ESCCB and the ACR: Is It the Same Fight? Reading on Others' Ideology: A

Pragmatic Analysis of the CNN and BBC Websites

directive act is "He also told them to protest peacefully but encouraged them to go to the Capitol and have their voices heard" where the writer indicates that Trump called on the rioters to peacefully go home and that he just wanted their voices to be heard. He did not want violence or any clashes.

The expressive act can also be seen in sentences like "Donald Trump supporters forced their way into the US Capitol building, which is where the United States Congress meet to write laws for the country" where the writer is expressing irony as the place where laws are supposed to be made was breached by riots. He is expressing his rejection of breaking the law in the home of law. He used the word "forced their way" to express security resistance. In a sentence like "Traditionally, the inauguration ceremony which marks the moment that the president officially starts his or her new job takes place on the steps of this building, in January following the election" the writer is emphasizing the presidential inaugural ceremony taking place and expressing the fact that it was going to happen as if he did not see the real status of the battle. The writer was sure that this would happen. In a sentence like "However, some of the protesters - some of them armed - decided to force their way into the Capitol building, bringing down barriers and climbing walls, forcing their way past security" the writer is directing figures of cause to the armed protesters and emphasizes that they were responsible for any violence that could happen. The writer is setting up the knowledge in the minds of the readers about the protesters and their behavior, whereas in a sentence like "Those who managed to enter the building shouted and waved pro-Trump and US flags as they made their way around the halls of the building, demanding that the results of the latest presidential election should be overturned" the writer expresses their rejection again of the entrance and that they are not the only one to feel that. The speech reflects that there were violence and resistance from security and that was more evidence of violence. The writer used "Members of the Congress had to hide under seats as tear gas was fired and there were clashes between protesters and the police, with some turning violent" where they are expressing the feeling of the Congress members as fear and caution and the scene was reflecting a terrorism act in the place of formulating laws against terrorism. The speech act indicates or describes a status of sorrow and seriousness and danger. In a sentence like "Protesters occupied the building for more than three hours before it was successfully secured by law enforcement" the word "occupies" here is reflective as it shows that this was not their right and they did not have to do what they did. Another example is "The events that took place in the Capitol building are unprecedented, which means they don't happen very 
The ESCCB and the ACR: Is It the Same Fight? Reading on Others' Ideology: A

Pragmatic Analysis of the CNN and BBC Websites

often" expressing denial of what happened and its rareness. The speech act describes a status of sorrow and seriousness or danger. Biden is talking about democracy; however, it is a hidden attack on Trump. In the writer's opinion, Trump could not be a president again or represent democracy as he refused the election's results. The writer expresses his disappointment about what happened using a sentence like "Barack Obama described the events at the Capitol as 'a moment of great dishonor and shame for our nation' in a statement and George W Bush described the events as 'a sickening \& heartbreaking sight."' The previous presidents also rejected what took place and they were strongly affected by it. The use of "a sickening heartbreak sight" is very effective here to express their shock of the incident. In a sentence like "After he was grabbed by his helmet and dragged face-first down several steps, he said the crowd started stripping gear from his vest, including spare ammo, his radio and his badge - all while chanting 'USA!'" this expression shows that it was not a peaceful riot. They were not trying to make their voices heard as Trump suggested where the violence here was not against the election or they were not expressing anger about the election but dealing with the representative people of the government.

As for the representatives, they can be seen in the following examples. "Washington DC riots: What happened?" is an attractive title to let people know what happened and at the same time correct any misconceptions as an official declaration of what happened. The writer is setting up mental knowledge for the readers. Another example is in the sentence "Thousands of protesters gathered outside the Capitol building" where the writer expresses the unusual status of protesters and that they could not be controlled by the security, thus giving an excuse for any unsecured attacks of the protesters and any violence that could have happened from this considerable number of people. In the sentence "America saw big riots in Washington DC on Wednesday" the writer uses the country's name to represent the sudden event for all the Americans and that it was an unusual and unexpected act for all. Another example is "The riots turned violent, with protesters clashing with the police. Five people died during the events and a number of police officers were also injured" where the writer here describes the scene as a fight between the protesters and the police giving numbers of the dead people and the injured ones which might be more according to the scene and the number of protesters mentioned before. He used words that represent action and fighting like "violent" and "clashing" and mentioned that people died, and others are injured. All these terms represent violence in the scene and parallel action where in the same place a law was declared, and the same law was being broken. 
The ESCCB and the ACR: Is It the Same Fight? Reading on Others' Ideology: A

Pragmatic Analysis of the CNN and BBC Websites

In "it was also confirmed that the Democratic party had taken political control of the Senate" the writer here declares that the new government had taken control and these riots are no longer affecting the Americans' decision assuring that the American capital is not a place for fighting or violence. Writers expressed rioters' violence using different words; however, all of them are effective such as "We got one! We got one!' Mr Fanone said he heard people shout, with others chanting: 'Kill him with his own gun!'” where the writer is asking people to kill the officer as a kind of violence not to go and let their voices be heard. However, Trump's supporters poorly represented him.

\section{CNN Network}

On the CNN network, the situation was different as commissives are rare This includes a hidden commissive act to repair what the writer sees as a defect in the present government. The writer states "a blatant and appalling disregard for our institutions of government and the orderly administration of the democratic process" and informs about it to represent a defect in Trump's government and the whole democratic system. In "He said agents and analysts have been gathering evidence, sharing intelligence, and working with federal prosecutors to bring charges" there is a commitment to punishing the participants in the riot. Also, in "The 25th Amendment has periodically been discussed as a means of last resort to remove a rogue or incapacitated president" the writer is declaring a refinement of the American policy in the future and commitment to protecting the country from an incapacitated president. Therefore, this is a commissive act to the Americans to be safe and away from any future acts like that of the Capitol riot. Then in " "because you'll never take back our country with weakness, you have to show strength and you have to be strong,' he said at his rally on the Ellipse" the writer's use of expressions of incitement to violence in this part is not just telling their opinion and that having a weapon is clear proof of using power in the building and how Americans feel about terrorism and how they can easily get in and commit crimes. This is an explicit request from his supporters to go to the Capitol Building and enter in such large numbers to a place where some of the decision-makers think that they will support him, but he noted the opposition of some in his expression. Meanwhile in "McConnell calls for investigation into Capitol security breach" this is a commissive act that reflects that they were going to restore stability and spread safety again and at the same time inflict a strong punishment on the involved ones. It is an indication that America is a country of law and accountability. 
Declaratives are more used here maybe to control the situation. For example, in "John Kelly says he'd vote to remove Trump if he were still in the Cabinet" the writer declares that Trump was unfit for the position and expresses rejection of his policy in controlling and treating the situation. Then the use of "US Capitol Police chief is resigning" is a declaration that the Capitol Police Chief was no longer in his position and that he was against what happened, considering it a disaster or catastrophe in US history and his past work as well. He refused the riot and expressed his rejection by resigning. In "Trump publicly acknowledges he won't serve a second term in video message" the writer declares Trump's dereliction and fault in directing his supporters to go to the Capitol and maybe disappointment about what happened. In "Make no mistake about this. It was a very dangerous situation. We are aggressively trying to address these cases as soon as possible," the writer announces the pursuit of those involved in the matter because it represents a great danger to the Americans, whereas in "Senate Democratic leader: 'This president should not hold office one day longer', the writer declares refusal of Trump being a president anymore and the end of his presidency. In the title "850 National Guard members will work in 12-hour shifts to secure Capitol grounds" the writer declares that the situation was controlled and things were getting back to normal. However, this act is very rare in the reports about the Egyptian situation.

Directives are used a lot and may be the most used act. The use of "I think it would be a distraction right now" and "is warning about the continuous of Trump in the American scene" and then using "We want to know how you're feeling. Let us know using the text box below" directs people to blame the riots and refuse their activity. In sentences like "The Cabinet should meet and have a discussion, 'said Kelly. I don't think it will happen. But I think the Cabinet should meet and discuss this" the writer refuses Trump's policy and deeds and asks for his removal from his position. Then in "Sen. Chris Coons, a Democrat from Delaware, fears that President Trump may put the US in a precarious position during his last days in office" the writer again warns about the precarious situation for the US if Trump was still there, whereas in "The police response to rioters storming the US Capitol on Wednesday was a message on 'double standards' around race for young people of color in the country, CNN commentator Van Jones said" the writer is trying to justify reasons for the riot away from Trump and his deeds. He is directing people to issues of color and racism in America. Hidden support for Trump based on color and racism is clearly indicated. He is telling or emphasizing injustice. Also, in “Trump's 'entire legacy was wiped out 
The ESCCB and the ACR: Is It the Same Fight? Reading on Others' Ideology: A

Pragmatic Analysis of the CNN and BBC Websites

yesterday,' she said. “... We cannot condone the violence. ... We need to have leadership more than ever right now in our country. We've got to rebuild our nation and rebuild our party" the writer expresses rejection of violence and the use of the pronoun "we" indicates that she is talking about all Americans and that the new president should start building the country that Trump and his supporters distorted. She is against violence and reporting her opinion about what happened and Trump's role in the rioters' behaviors and deeds inside the Capitol. In using "domestic terrorism" it is a directive act to the authority of the country and the police or the FBI to pay attention to terrorism acts and that they should take actions about that. Moreover, in "The former first lady noted that the BLM protests across the country this past summer were an 'overwhelmingly peaceful movement' that brought together people of "every race and class" she is directing the reader to think about both actions and find out for themselves how black people are peaceful whereas white people are chaotic in behavior. She praises or prefers using power for protesters to control them. That is racism in America. Also, in " And yet, in city after city, day after day, we saw peaceful protesters met with brute force, she added" she directs the reader to see the danger of future similar actions. They could see protesters with brute force and this word indicates a warning against violence that may happen in the near future if it is left without treatment with power. In a sentence like "Americans are, in fact, allowed to denigrate the flag and symbols of our nation. They've just got to look the right way," there is a hidden request to stop these people and be keener about the nation's symbols and flag. Moreover, "Such behavior betrays the values of our democracy" holds a hidden directive act to stop such behaviors and raise the value of domestic democracy. Furthermore, in "Despite promising he would join them, Trump retreated to the White House in his SUV and watched on television as the violence unfolded on Capitol Hill" this behavior was not President Trump's responsibility and at the same time implicated his supporters in storming the building and making such a mistake that made him withdraw his confidence and lose his credibility with the American people. Also, "So count this office is trashed. You can see the debris is all over the floor, ' he says" fills the reader psychologically and provokes feelings of resentment and anger that already exist in the American reader and viewer. This reflects the obvious losses in place caused by violence and vandalism.

Headlines here, play a core role with writers. In "America suffered an unprecedented attack on its democracy yesterday. We want to hear from you" the writer requests that people cooperate and come to talk about the event's details that they know. Also, in "Police response during riots at the US Capitol show 
'double standards' around race, Van Jones says' the writer is trying to impose another point which is racing in the situation. A double treatment here reflects no standards for treating humans in America, which is not the case or point of the riot. In a title like "Black protesters are treated 'completely different,' BLM cofounder says" the writer speaks about social standards in treating black people and racism, criticizing the social life in America and ideology about individuals and racism. Also, in "FBI asks public to help identify rioters" the writer directs the community to help identify the rioters and indicates a hidden threat that they will be punished. Then in "Democratic senator fears Trump may get the US 'into some sort of conflict' in his last days" the writer warns about US conflict between people and instability if Trump would continue in his position of US president. Accordingly, he is also directing the reader to Trump's removal even if the election supported him. The writer is reporting on and informing about stolen things from the building. Finally, in "Here's what Trump told a crowd of supporters yesterday before the riot" the writer evokes the feeling of anger against Trump and directs the individuals to ask for or justify his being ousted from power.

As for expressives which are the most used act as writers play on the emotional part to affect readers, the writer used "You can't not have concerns about his mental fitness when you see the way he behaves, the way he acts and the things he does,' said Powell" to criticize Trump's deeds and behavior. In "The attack comes during the deadly coronavirus pandemic that has already turned life upside down. ..." the writer blames the riots for not considering the pandemic status and not considering the state condition during the pandemic. In the sentence "... that left lawmakers and staff fearful for their lives" the writer expresses blame and refuses the activity as lawmakers were afraid of losing their lives. In a sentence like "Livestream video appears to show a Capitol Hill police officer taking a selfie with a rioter inside the building" the writer expresses carelessness and remissness where people were storming the Capitol and insecurity was surrounding them at the same time and it may reflect the involvement of some of the officers as said about the riot. Reflexives and impressives at the same time indicate peace and amicable, friendly treatment of the police with the rioters. Then "'It was not dissent, it was not disorder, it was not protest,' he said. "It was chaos. Don't dare call them protesters. They were a riotous mob. Insurrectionists. Domestic terrorists" inflamed people against Trump and his supporters and against strengthening his victory in the election and having trust in him and that they were right to choose him. Moreover, in "Biden called yesterday one of the 
The ESCCB and the ACR: Is It the Same Fight? Reading on Others' Ideology: A

Pragmatic Analysis of the CNN and BBC Websites

darkest days in the history of our nation and reiterated that it was an "unprecedented assault on our democracy" there is a hidden message that the USA is a country that respects democracy and all along history they were a model representing peace and democracy for all. Biden is blaming Trump for the unprecedented assault on the USA's democracy. Moreover, in "The behavior..."What happened on Capitol Hill yesterday is a direct result of his poisoning the minds of people with the lies and the frauds" he blames Trump for everything that people did. This act also confirms that Trump was unfit and that close people around him witnessed his uncontrolled thoughts and behaviors. In "What happened yesterday is because millions of people across the country were misled by Republicans ... she added" the writer denies what Trump said about the election overturn and usurpation and that he misled the people by stating the current situation and condemning what happened and the act here holds a strong hidden attack against Trump. The writer expresses fear of the future with this current violent situation that could affect the whole country. The statement also holds a directive act. Enforcing the law and holding the accountability of all who could threaten the democracy of the nation is requested. In "tore things off the walls, 'including art from a renowned artist, showed a Trump 2020 flag that was left behind and stole a laptop that sitting on a table. He also shows a cigarette butt that was stamped out" it shows intentionally sabotaging the place and destroying all its artistic features, as well as behaving in an inappropriate manner using a cigarette, which reflects a feeling of revenge on those who invaded the place and their deliberately barbaric behaviors. Then in "I haven't felt that way in over 15 years since I was a ranger in Iraq and Afghanistan, where I thought there was a possibility, I would have to fight my way out" there was fear and terror of being held in a place that could cost him his life.

Titles also play a core role using this act like in "House representative: I haven't felt like this "since I was a ranger in Iraq and Afghanistan" expressing astonishment and amazement at what happened and comparing it to a place like Afghanistan that would ignite the reader against violence and its users. Reporting about the activity of representatives can show the whole story and direct the reader to reject and feel danger about the society. This also expresses the shock of the people inside the Capitol and that that was an unusual or unexpected action to them. Furthermore, "Michelle Obama says Pro-Trump rioters were "allowed to denigrate the flag and symbols of our nation" indicates that the Americans care about their symbols and refuse what can denigrate their nation. The action represents them contrasting their ideology in the world. The words "were 
allowed" indicate the laxity or indolence of Trump's security or the classness of the nation's reputation by allowing his followers to denigrate the nation's symbols and flag. He could not control them. Also, in "DC Mayor deems riots at the Capitol as 'textbook terrorism' and calls for statehood" the leaders of the society represent the attitudes and thoughts of their community, and this is clearly expressing refusal of violence and describes the rioters' actions as terrorism. Also, "Biden ... 'darkest days in the history of our nation"" expresses shame and regret about the activity and that this act was usual and strange for the society.

The best way to achieve targets with words is to use the representative act as it is considered in the press as live and real from place to catch people's attention. In a sentence like "Despite his opposition to removing Trump by a constitutional mechanism, Powell still suggested he believes Trump is unfit to occupy the Oval Office" the writer refuses Trump as a president for America. “... Capitol Police and other law enforcement officers were 'actively attacked' with metal pipes and other weapons" states and reports the process of storming the Capitol and the danger the officers faced during that time. " They were determined to enter into the Capitol Building by causing great damage" Sund said" informs the reader about the damage and losses due to the rioters' actions. Also, "I wish we could say we couldn't see it coming. But that wasn't true. We could see it coming,' he said" states the unprecedented assault on their democracy and a hidden promise to restore their position. Furthermore, "Biden had harsh words for Trump, condemning him for attacking the free press and independent judiciary and using tactics long-used by autocrats and dictators all over the world" states that Trump is an autocrat and dictator, making him unsuitable for the democratic policy in America. It seems that it was a fight against Trump, not condemning the riot itself. A sentence like "In the video, released more than 24 hours after Wednesday's riot, Trump made calls for "healing and reconciliation" and said the country must move forward" suggests getting back and calming the storm, asking for reconciliation, and feeling guilty. In other places, writers report about the American society and how they live, expressing society's ideology about African and white people. How the police treated the black individuals inside the Capitol is an indication of the whole society. Also, "This is some of the damage and debris still seen throughout the US Capitol building today after a violent mob stormed the building Wednesday afternoon" reports the damage that happened and directs the reader against the action itself. Moreover, in "In her statement today, former first lady Michelle Obama pointed out the differences in how the behavior of Black Lives Matter protesters and Pro-Trump rioters was treated by the authorities" 
there is a hidden meaning regarding some people involved in the act to show how black people are treated and again the case of racism. The sentence "Sherwin said 'most of those cases' relate to unauthorized entry to the Capitol and the Capitol grounds. He said they were also filing cases involving firearms and theft of property" informs about the real reason behind the Capitol riot which is not policy but stealing and theft of property and firearms. There is an indication that Trump's supporters are not responsible people. They are chaotic and barbarian. Also, "He said one man was arrested by federal agents with a military semi-automatic rifle and 11 Molotov cocktails that were ready to go" states information about the riot. Riots are not an expression of opinion or supporting a political party but breaking the law and stealing property. Then in "President Trump spoke at a rally in DC on Wednesday before the Pro-Trump rioters storming the US Capitol. Also at the rally, he encouraged his supporters to protest at the US Capitol" this behavior is an explicit condemnation of Trump's incitement of his supporters to storm the Capitol, carry out acts of sabotage there, and steal some of its contents. Also, in "stole a laptop that was on a table" the writer states that the rioters might have been looking for information to take a laptop. Then in "US Capitol Police chief is resigning" the writer states the chief's carelessness and apologizes to the USA society and leaders' community. "Capitol Police officer on life support after proTrump riot, union official says" informs about the status of the officer and representing his case to the Americans to make them aware of the results of the events which is also a directive act to refuse the action and not to sympathize with any of the rioters. Then "DC police release photos of dozens of people wanted in US Capitol riots" reports about the photos and proves asserting and justifying who was involved in the event. As for the Egyptian court event writers hardly wrote and reported about it as in "Egypt's highest court has stopped its work indefinitely in protest at the pressure being put on them by Islamist groups" reporting only about the event.

Representing sorts of violence and spreading images and using words are all tools to express the rejection of the society of all types of violence. Writers used different ways to show this. In "Eventually, the lawmakers were told to evacuate" there was a sort of violence. Then "smashed the door virtually off its hinges. He said the door was unlocked" indicates that the place was vandalized and destroyed, not just burglarized, because the door was open, so it did not need to be broken, whereas the sentence "domestic terrorism" is very impressive as this was the first time Americans feel terrorism and how they can easily get into and commit crimes. The writer's use of expressions of incitement to violence in this 
The ESCCB and the ACR: Is It the Same Fight? Reading on Others' Ideology: A

Pragmatic Analysis of the CNN and BBC Websites

part is not just telling their opinion and having a weapon is clear proof of using power in the building. Because of all this text and variety of acts, one can get many results as in the following section.

\section{Results and Findings}

The meanings which are activated on reading depend on the interaction between the text and reader. Americans focused on the personalities and motivations of the characters in making their readings coherent, as shown in the Analysis part. Pragmatics, as mentioned above, is the study of meaning which is related to speech situations. Thus, Yule (1996) argues that pragmatics should consider aspects of context such as to whom people are talking and when, where, and under what circumstances which will determine the way they say and what they want to say. It is important to know that when using Internet network publishing one talks to all who can access it. Therefore, the message here is directed to the whole world. In addition, people talking represent their whole community if the government agrees on what they are writing or saying. From the previous analysis, the status can be as follows.

Concerning types of speech acts, as illustrated in Table 1, the findings of analysis indicate that assertive speech acts have the highest percentage of the speech acts employed. According to Searle (1979), in assertives, the speaker is committed to something being the case. The vast majority of assertives are used in the text and few are used in headlines on CNN and BBC. Moreover, most of the reports used have the illocutionary force of "informing" the reader about what is happening or "exposing" some facts in the news about the violence and rioters" behaviors inside the Capitol. Therefore, according to the procedure adopted, these acts will be considered to "expose" or "report" which lie in the second level of the model of analysis and are directly related to the first level, i.e., assertives. Table 2 shows the types of speech acts employed in the CNN and BBC data, in addition to the percentage of the frequency of their appearance in the data. The assertive speech acts outnumber other speech acts and are identified with a frequency of appearance that amounts to 47 in $\mathrm{CNN}$ with a percentage of $35.60 \%$ and 3 in $\mathrm{BBC}$ with a percentage of $33.33 \%$. This can be attributed to the fact that the main function of assertives here is to report or expose the current state of affairs. 
The ESCCB and the ACR: Is It the Same Fight? Reading on Others' Ideology: A

Pragmatic Analysis of the CNN and BBC Websites

Table 2: Types of speech acts related to ACR.

\begin{tabular}{|c|c|c|c|c|c|c|c|c|c|c|c|c|c|}
\hline \multirow{2}{*}{$\begin{array}{r}\text { Types } \\
\text { and } \\
\text { network } \\
\mathrm{s}\end{array}$} & \multicolumn{2}{|c|}{$\begin{array}{c}\text { Representati } \\
\text { ves }\end{array}$} & \multicolumn{2}{|c|}{$\begin{array}{c}\text { Expressiv } \\
\text { es }\end{array}$} & \multicolumn{2}{|c|}{$\begin{array}{l}\text { Commissi } \\
\text { ves }\end{array}$} & \multicolumn{2}{|c|}{ Directives } & \multicolumn{2}{|c|}{$\begin{array}{c}\text { Declarativ } \\
\text { es }\end{array}$} & \multicolumn{2}{|c|}{ Total } & \multirow{2}{*}{$\stackrel{\text { 풍 }}{\ominus}$} \\
\hline & $\mathrm{BBC}$ & $\begin{array}{c}\mathrm{CN} \\
\mathrm{N}\end{array}$ & $\begin{array}{c}\text { BB } \\
\text { C }\end{array}$ & $\begin{array}{c}\mathrm{CN} \\
\mathrm{N}\end{array}$ & $\begin{array}{c}\text { BB } \\
\text { C }\end{array}$ & $\begin{array}{c}\mathrm{CN} \\
\mathrm{N}\end{array}$ & $\begin{array}{c}\mathrm{BB} \\
\mathrm{C}\end{array}$ & $\begin{array}{c}\mathrm{CN} \\
\mathrm{N}\end{array}$ & $\begin{array}{c}\mathrm{BB} \\
\mathrm{C}\end{array}$ & $\begin{array}{c}\mathrm{CN} \\
\mathrm{N}\end{array}$ & $\begin{array}{c}\mathrm{BB} \\
\mathrm{C}\end{array}$ & $\begin{array}{c}\mathrm{CN} \\
\mathrm{N}\end{array}$ & \\
\hline Titles & 2 & 8 & - & 5 & - & 1 & 1 & 6 & - & 8 & 5 & 28 & 33 \\
\hline Text & 10 & 39 & 13 & 32 & 9 & 4 & 9 & 23 & 3 & 6 & 43 & 104 & 14 \\
\hline
\end{tabular}

Table 3: types of speech acts and their percentages in $\mathrm{CNN}$ and $\mathrm{BBC}$ websites regarding ACR.

\begin{tabular}{|c|c|c|c|c|c|c|c|c|c|c|c|}
\hline \multirow{2}{*}{$\begin{array}{l}\text { Speech act } \\
\text { News } \\
\text { website }\end{array}$} & \multicolumn{2}{|c|}{$\begin{array}{l}\text { Representat } \\
\text { ives }\end{array}$} & \multicolumn{2}{|c|}{ Directives } & \multicolumn{2}{|c|}{$\begin{array}{l}\text { Commissiv } \\
\text { es }\end{array}$} & \multicolumn{2}{|c|}{ Expressives } & \multicolumn{2}{|c|}{$\begin{array}{l}\text { Declarativ } \\
\text { es }\end{array}$} & \multirow{2}{*}{$\begin{array}{l}\text { Tota } \\
1 \\
\text { No }\end{array}$} \\
\hline & No & $\%$ & No & $\%$ & No & $\%$ & No & $\%$ & No & $\%$ & \\
\hline $\mathrm{CNN}$ & 47 & 35.6 & 29 & 21.9 & 5 & 0.03 & 37 & 28 & 14 & 10. & 132 \\
\hline $\mathrm{BBC}$ & 12 & 27 & 10 & 18.7 & 9 & 0.08 & 13 & 29.1 & 3 & 16. & 48 \\
\hline
\end{tabular}

Looking at the table of Capitol riot statistical results in both sites, the total numbers of speech acts in BBC is 48, the highest of which is expressives at 13 and a percentage of $27.0 \%$, followed by representatives or assertives at 12 and a percentage of $25 \%$ and directives at 3 and a percentage of $0.06 \%$ which indicate the British ideology of refusing the action of getting in the Capitol in this way. These are followed by declaratives at 10 and a percentage of $20.8 \%$. The least one is declaratives at 3 and a percentage of $0.060 \%$. The case in CNN is different where the assertives are the highest at 47 and a percentage of $35.6 \%$, followed by representatives at 37 and a percentage of $28 \%$, then directives at 29 and a percentage of $21.9 .0 \%$, then declaratives at 14 and a percentage of $10.6 \%$, and finally commisives at 5 and a percentage of $0.03 \%$. This indicates that the Americans are keen on explaining the actual situation to the whole world, showing their real feelings attached with instructions and directing readers to the correct behavior and having some firm determined actions through the declaratives to show their control over the situation and commitment to the law. 
The ESCCB and the ACR: Is It the Same Fight? Reading on Others' Ideology: A Pragmatic Analysis of the CNN and BBC Websites

Table 4: Types of speech acts and percentages in $\mathrm{CNN}$ in relation to $\mathrm{CR}$ and ESCCB.

(1) CNN/ACR

\begin{tabular}{ccc} 
Speech act type & Frequency & Percentage \\
\hline Assertive & 47 & $35.606 \%$ \\
Directive & 29 & $21.970 \%$ \\
Commissive & 5 & $3.788 \%$ \\
Expressive & 37 & $28.030 \%$ \\
Declarative & 14 & $10.606 \%$ \\
\hline Total & 132 & $100.000 \%$ \\
\hline
\end{tabular}

(2) CNN/ESCCB

\begin{tabular}{ccc}
\hline Speech act type & Frequency & Percentage \\
\hline Assertive & 3 & $33.333 \%$ \\
Directive & 1 & $11.111 \%$ \\
Commissive & 0 & $0.000 \%$ \\
Expressive & 3 & $33.333 \%$ \\
Declarative & 2 & $22.222 \%$ \\
\hline Total & 9 & $100.000 \%$ \\
\hline
\end{tabular}

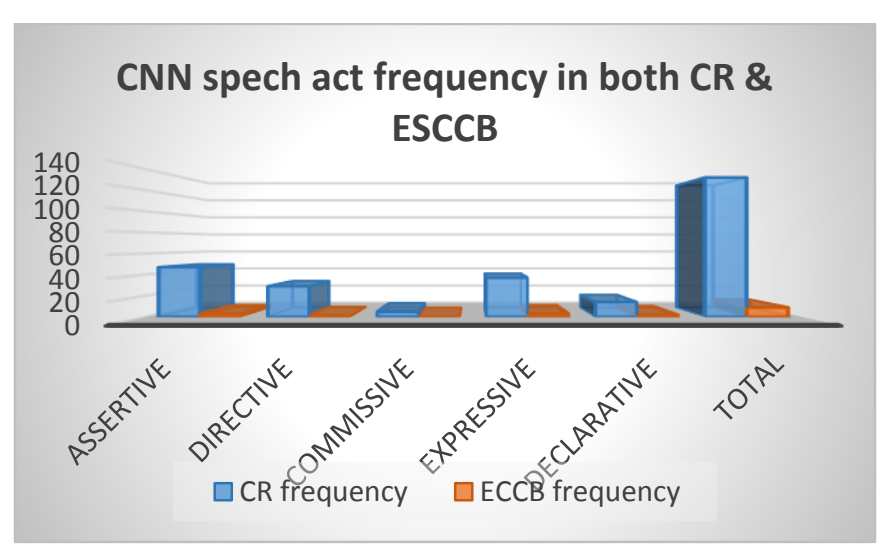

Figure r: Picture of the distribution of the speech acts employed on the CNN website.

Table 5: Types of speech acts related to ESCCB.

\begin{tabular}{|c|c|c|c|c|c|c|c|c|c|c|c|c|c|}
\hline \multirow{2}{*}{$\begin{array}{r}\text { Types } \\
\text { and } \\
\text { network }\end{array}$} & \multicolumn{2}{|c|}{$\begin{array}{c}\text { Representati } \\
\text { ves }\end{array}$} & \multicolumn{2}{|c|}{$\begin{array}{c}\text { Expressiv } \\
\text { es }\end{array}$} & \multicolumn{2}{|c|}{$\begin{array}{l}\text { Commissi } \\
\text { ves }\end{array}$} & \multicolumn{2}{|c|}{ Directives } & \multicolumn{2}{|c|}{$\begin{array}{c}\text { Declarativ } \\
\text { es }\end{array}$} & \multicolumn{2}{|c|}{ Total } & \multirow{2}{*}{ 丞 } \\
\hline & $\mathrm{BBC}$ & $\mathrm{CN}$ & BB & $\mathrm{CN}$ & BB & $\mathrm{CN}$ & BB & $\mathrm{CN}$ & BB & $\mathrm{CN}$ & BB & $\mathrm{CN}$ & \\
\hline Titles & 1 & - & - & - & - & - & - & - & - & 2 & 1 & 2 & 3 \\
\hline Text & 3 & 3 & 1 & 3 & - & - & - & 1 & - & - & 4 & 7 & 11 \\
\hline
\end{tabular}

Table 6: types of speech acts and their percentages on the CNN and BBC websites regarding ESCCB.

\begin{tabular}{|c|c|c|c|c|c|c|c|c|c|c|c|}
\hline $\begin{array}{c}\text { Speech act } \\
\text { Netys } \\
\text { website }\end{array}$ & \multicolumn{2}{|c|}{$\begin{array}{c}\text { Representat } \\
\text { ives }\end{array}$} & \multicolumn{2}{l|}{ Directives } & \multicolumn{2}{c|}{$\begin{array}{c}\text { Commissiv } \\
\text { e }\end{array}$} & \multicolumn{2}{l|}{ Expressives } & \multicolumn{2}{|l|}{ Declaratives } & $\begin{array}{c}\text { Tot } \\
\text { al }\end{array}$ \\
\cline { 2 - 14 } & No & $\%$ & No & $\%$ & No & $\%$ & No & $\%$ & No & $\%$ & No \\
\hline CNN & 3 & 33.3 & 1 & $11 \%$ & 0 & $0 \%$ & 3 & 33.3 & 2 & 22.2 & 9 \\
\hline BBC & 4 & $80 \%$ & 0 & $0 \%$ & 0 & $0 \%$ & 1 & $20 \%$ & 0 & $0 \%$ & 5 \\
\hline
\end{tabular}


Looking at table (5) related to ESCCB statics, the total number of speech acts in $\mathrm{BBC}$ is 5 and it is a very small number for an event like that. However, it may be so for the situation and context of the Arab Spring events. Only two types of speech acts are present. The highest of them is assertives or representatives at 4 and a percentage of $80.0 \%$, followed by expressives at 1 and a percentage of $20 \%$. The case is different with CNN, where representatives come first at 3 and a percentage of $33.3 \%$, exactly the same as expressives. These are followed by declaratives at 2 and a percentage of $22.2 \%$ and finally directives at 1 and a percentage of $11 \%$. However, commissives are not present. This indicates that the Americans agree with the British in their ideology.

Table 7: Types of speech acts and percentages in $\mathrm{BBC}$ in relation to $\mathrm{CR}$ and ESCCB.

(1) $B B C / A C R$

\begin{tabular}{ccc}
\cline { 2 - 3 } Speech act type & Frequency & Percentage \\
\hline Assertive & 13 & $27.083 \%$ \\
Directive & 9 & $18.750 \%$ \\
Commissive & 4 & $8.333 \%$ \\
Expressive & 14 & $29.167 \%$ \\
Declarative & 8 & $16.667 \%$ \\
\hline Total & 48 & $100.000 \%$ \\
\hline
\end{tabular}

(2) BBC/ESCCB

\begin{tabular}{ccc} 
Speech act type & Frequency & Percentage \\
\hline Assertive & 4 & $80.000 \%$ \\
Directive & 0 & $0.000 \%$ \\
Commissive & 0 & $0.000 \%$ \\
Expressive & 1 & $20.000 \%$ \\
Declarative & 0 & $0.000 \%$ \\
\hline Total & 5 & $100.000 \%$ \\
\hline
\end{tabular}

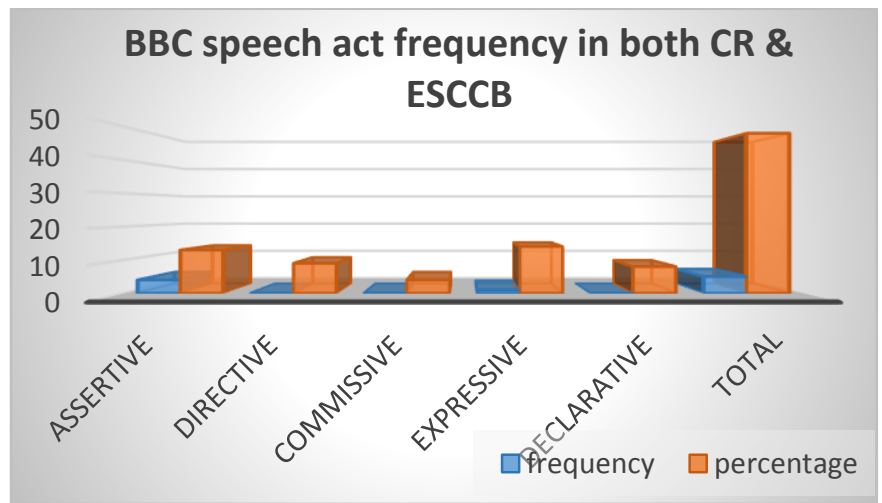

Figure s: Picture of the distribution of the speech acts employed on the BBC website.

Concerning functions of speech acts, all the types of speech acts' utterances have the functions of stating complaining, alerting, claiming, reporting, affirming, forecasting, asserting, demanding, requesting, suggesting, promising, refusing, blaming, praising, mocking, being ashamed, and declaring. It can be concluded that the kind of speech act used most by CNN writers is the representative act of stating, reporting refusing, and mocking. The first type of assertive act is belief. 
This act refers to something that will be getting done in the future. The second type of assertive act is assumption. This utterance refers to something that can be true or false from the speaker. The third type of assertive act is information. This utterance refers to something that happened with the speaker in the past. It can be proven by the data. The fourth type of assertive act is affirmation. This utterance seems like the supporting phrase or sentence to something that has been known. According to the results above, it is found that BBC does not employ all the five types classified by Searle (1979). The highest in both sites are representatives because these acts are used to indicate the current situation. Most of the propositions covered by way of expressive speech acts are related to the refusal of Trump in presidency any longer and the Americans' refusal of the rioters' deeds. This indicates that BBC showed a more neutral attitude towards both events' coverage but with refusing violence and respecting the law, and so did CNN. Declarations are not used in BBC because the context is not that of declaring certain actions by certain people rather than stating things. Figure 2 indicates the distribution of the speech acts used in $\mathrm{BBC}$. With respect to functions of speech acts used in the $\mathrm{BBC}$ and $\mathrm{CNN}$, the second research question has been addressed.

It is also noticed that implicit speech acts are fewer than explicit speech acts in both news websites. This employment may be attributed to the fact that reporters want to avoid direct reference to the propositions included in the reader's attention. Table (8) below also presents a breakdown of the speech acts employed. The illocutionary act refers to the specific force associated with the uttering of particular words in a particular context. This suggests that illocutionary force at some level and at some point, in time is playing a role in the comprehension and representation of these sentences. Both sentences and the performative verbs in the sentence are representing the implicit intentions of the writers. Recognition of the illocutionary force of implicit performatives represents an inference process of sorts; the speech act verb is not literally present in the sentence and must be inferred. These inferences are made as a means of explaining why various actions have occurred in the text, as a result of a general search after meaning. Spontaneous trait inferences are inferences made about a person that occur when one is comprehending a description of that person's behavior. In a sentence like "stole a laptop that was on a table" the implicit meaning is that they are thieves not protesters. This performative verb stole activates the illocutionary force of not only rejecting them but accusing them also with being thieves and terrorists. The explicit performative verbs used in illocutionary acts activate the illocutionary 
force inside the reader to reject the action and support their country. Another sentence like" We got one! We got one!' Mr Fanone said he heard people shout, with others chanting: "Kill him with his own gun" can be recognized as containing an illocutionary force that activated holding hostility against the officers in general and against the new government by the new president. Reading the illocutionary force is one of the big challenges in this study.

Table 8: Implicit and Explicit Speech Acts about ACR

\begin{tabular}{|l|c|l|l|l|c|}
\hline \multirow{2}{*}{ act } & \multicolumn{2}{l|}{ Speech } & \multicolumn{2}{l|}{ Implicit } & \multicolumn{2}{l|}{ Explicit } & \multirow{2}{*}{ Total } \\
\cline { 2 - 6 } & No & $\%$ & No & $\%$ & \\
\hline CNN & 14 & $10.9 \%$ & 118 & $89 \%$ & 132 \\
\hline BBC & - & $0 \%$ & 48 & $100 \%$ & 48 \\
\hline
\end{tabular}

Table 9: Implicit and Explicit Speech Acts about ESCCB

\begin{tabular}{|l|c|c|c|c|c|}
\hline \multirow{2}{*}{ act } & \multicolumn{2}{|c|}{ Speech } & \multicolumn{2}{|c|}{ Implicit } & \multicolumn{2}{|c|}{ Explicit } & Tota \\
\cline { 2 - 6 } & No & $\%$ & No & $\%$ & 1 \\
\hline CNN & - & $\% \cdot$ & 9 & $100 \%$ & 9 \\
\hline BBC & - & $\% \cdot$ & 5 & $100 \%$ & 5 \\
\hline
\end{tabular}

According to the results above, it is found that BBC does not employ all the five types classified by Searle (1979). With respect to these types, declarations are not used in the BBC. With the abundant use of violent words referred to in the Analysis part, the Second research question has been answered. The ideology of all the Americans and the British governors, writers, or individuals refuses violence and calls for respecting the law. This can be attributed to the fact that assertives are used to give truthful information to the reader. Data analysis shows that explicit speech acts have higher percentages of employment than implicit speech acts in the two websites. Consequently, the third question has been addressed.

The data analysis demonstrates that there are some similarities and differences between the websites of both networks. Both websites' writers show preference towards assertive speech acts. The results also indicate that both manifest a preponderance of representative speech acts. BBC, on the other hand, is marked by the nonoccurrence of declarations. One reason is related to the nature of their reporters who are not able to give orders or issue commands. Directive speech acts are higher on CNN than they are on BBC to guide the citizens to relax and keep peace in the country. Part of the analysis comes under Halliday (1985), where the use of words is indicative and words are used to express the attitudes and ideology of the writers. By using explicit and implicit utterances, the writers can 
deliver their intention through direct and indirect utterances. Both direct and indirect utterances have their function where a direct utterance functions when there is a relationship between the form of the utterance and its function. Meanwhile, an indirect utterance is used to make an indirect relationship between the form of the utterance and its function. Yule (1996) says that the use of an indirect utterance can be considered with more polite than a direct one. Thus, the theory of speech acts is the theory of how the writers accomplish their intention using certain utterances. The utterances can be a declarative, an interrogative, or an imperative. The function of the utterances can be a statement, a question, or an order/request. All the forms and their functions in the utterances are to express a certain attitude, and the type of speech act that is performed corresponds to the type of attitude being expressed. For example, statements express a belief, a request expresses a desire, and an apology expresses regret. As an act of communication, a speech act succeeds if the reader identifies, in accordance with the writer's intention, the attitude being expressed.

Dealing with the functions of the representative speech acts, the analysis shows that the articles produced confirming, agreeing, disagreeing, explaining, informing, stating, predicting, describing, and identifying. Representative speech acts are used to commit the writer to the truth of the expressed proposition. In other words, the pragmatic intention of such utterances includes asserting, stating, claiming, reporting, announcing, and describing. With respect to the situational context of their utterance, some of the representatives are indicated by the use of assertive verbs, while others are inferred from the meanings of the sentences. The articles also contain various functions of directive speech acts. They are asking, requesting, suggesting, directing, reminding, warning, and persuading. They are the type of speech acts through which writers try to get the readers to do something supporting the state and rejecting the behaviors that tarnished America's image in front of the world. Concerning the function of expressive speech acts, the articles contain stating annoyance, stating dislike, and stating anger. They reveal the psychological state of the writers about the state of affairs in the USA. The most frequently used expressive speech act's function is revealed in the form of stating anger about Trump and his supporters. In terms of commissive speech acts, the articles produced one function, namely, promising to restore the USA's position. The Americans are against what happened in the Capitol: "It's appalling that Donald Trump would do this! He's just demonstrating to everyone why he doesn't deserve to be in power anymore! I hope Joe Biden will be better and will hopeful pull America out of this hole, Trump has created." They felt guilty about having 
Trump in his previous period and feel the same feeling as the Egyptians that he is no longer fit for this position. As for the Egyptians, they think that that is an unacceptable form of protest. They felt as if he was acting like a juvenile, which is humiliating for him. The Americans thought what the protesters did was unpalatable. They destroyed a part of America's history just because they could not bear the fact that Trump is not president anymore. For the Americans, what happened is a disgrace. In addition, they think that Donald Trump should be ashamed for causing this riot and causing many people to get injured.

The signs of unexpected violence appeared in the language used, for example, "We weren't battling 50 or 60 rioters in this tunnel, we were battling 15,000 people. It looked like a medieval battle scene." The writer wants to talk about the number of rioters who suddenly entered the Capitol in a chaotic behavior. He described the scene: "he was grabbed by his helmet and dragged face-first down several steps, he said the crowd started stripping gear from his vest, including spare ammo, his radio and his badge - all while chanting 'USA!'” This was miserable for a country like America. The officer in the scene represents the government, not Biden, who won the election. Therefore, the violence here is directed at the government. Biden came to power by election, not by the government that, in the eyes of Trump and his supporters, biased the election. The situation was dangerous as one of the officers said: "We were battling, you know, tooth and nail for our lives." One rioter tried to gouge his eyes. "That was one of the three times that day where I thought: Well, this might be it, 'said Mr Hodges. 'This might be the end for me' As he choked on tear gas, he is seen on video gasping for air to call out for help. Enough police were eventually able to push through the melee to extract him. Protesters called him a traitor." This description of rioters' treatment of people inside the Capitol meant that protesters intended to kill whomever they face. Signs of a strange attitude were also indicated about one of the protesters: "can be seen in photos roaming the Capitol halls shirtless, holding an American flag affixed to a spear in one hand and a bullhorn in the other." This may indicate that the rioters did not care about how they saw them or what could be said about America at that time. Why is he doing this? Why does he appear this way? What message is he sending to the world? "They were determined to enter into the Capitol Building by causing great damage," Describing protesters as a pro-Trump mob gives a negative attitude about Trump, who was at least recently the American president. Describing the American democracy "inside the halls of American democracy" gives the attitude of American greatness that is infected with a disease. Based on the analysis of the 
The ESCCB and the ACR: Is It the Same Fight? Reading on Others' Ideology: A

Pragmatic Analysis of the CNN and BBC Websites

reports' text, the words expressing violence are repeated many times, as in Table 10 (A) and (b)

Table 10A: Frequency of words of violence in ACR /Table 10B: Frequency of words of violence in ESCCB.

\begin{tabular}{|c|c|c|c|}
\hline \multirow{2}{*}{ Item } & \multicolumn{2}{|c|}{$\begin{array}{l}\text { Violent } \\
\text { wourds }\end{array}$} & \multirow{2}{*}{ Tota } \\
$\mathbf{1}$ & \multicolumn{2}{|c|}{} \\
\cline { 2 - 3 } & $\mathrm{BB}$ & $\mathrm{CN}$ & \\
\hline Titles & 1 & 9 & 10 \\
\hline Text & 44 & 123 & 167 \\
\hline
\end{tabular}

\begin{tabular}{|c|c|c|c|}
\hline \multirow{2}{*}{ Sources } & \multicolumn{2}{|c|}{$\begin{array}{c}\text { Item } \\
\text { words }\end{array}$} & $\begin{array}{c}\text { Tota } \\
\text { l }\end{array}$ \\
\cline { 2 - 3 } & BB & CN & \\
\hline Titles & - & - & - \\
\hline Text & 2 & 4 & 6 \\
\hline
\end{tabular}

For van Dijk (1996), ideologies apply to many different attitudes in different social domains. They are more fundamental or axiomatic and responsible for shaping mental representations and models that define different groups. They are shared so widely and may be a part of the "generally accepted attitudes of an entire community" as beliefs, opinions, or common sense. Ideologies represent social features of a group like identity, values, and resources. For him, media discourse has an effect in formulating models and social representations. Individuals primarily rely on the media to construct their models and mental representations, especially in issues where such personal models are lacking. The diversity of such models and mental representations in a society like America, where different types of people live together, depends on the diversity of information in mass media. At the same time, access to public discourse is restricted to those who serve the interests and ideologies of media institutions. For van Dijk, they control text and talk, and only their preferential and active access to public discourse is present. He states, "the routines, actors, events, and institutional arrangements in news making are biased towards the reproduction of a limited set of dominant, elite ideologies, and they only show what is benefit to them and serve this trend."

Media institutions employ several discourse structures to identify ideologies and reveal group struggles. This is seen when black people compared the Capitol riot with their movement and how the security treated them. One of the main concepts for van Dijk is the ideological square that aims to (i) emphasize positive things about us, (ii) emphasize negative things about them, (iii) deemphasize negative things about us, and (iv) deemphasize positive things about them. This is seen when writers referred to the Capitol riot as a first in America's life of democracy where they were deemphasizing terrorism about themselves and went on to exaggerate by saying that it is the darkest day in the nation's life. The meaning of discourse (here meaning the two events) is controlled by subjective interpretations of language used in the situation or events (here meaning the 
writers' language) the discourse is about, which is by their mental models. People understand a discourse if they can construct a model for it. Thus, news language on $\mathrm{CNN}$ and $\mathrm{BBC}$ in both events was typically produced and understood based on the subjective models of the writers and readers about both events. As is the case for context models, these "event models" may also be ideologically biased based on underlying, socially shared attitudes and ideologies. However, the Americans are not biased. The writers used the language of their mentality and the language that they can understand and already share as an attitude and their own beliefs or ideologies. All other socially shared beliefs and ideologies of groups are based on and presuppose the general knowledge of the community. Ideological group beliefs take different forms, depending on their social functions. Some beliefs may be expressed to influence social policy or promote a cause, as may be the case for the black racism movement that happened before the Capitol riot and about which Mrs. Obama spoke in the same context.

To sum up, and based on the previous results, the study has reached the following findings:

(1) Assertives or sometimes called representatives are mostly used on CNN and also on BBC news networks.

(2) Directives and declarations are very rare on BBC; and, they appear on CNN.

(3) Explicit speech acts are used more than implicit one on CNN and BBC networks.

(4) The study shows there is a relationship between the state's political, cultural, and economic ideologies and media coverage.

(5) Media is a tool in the hands of politicians where they use it to support their deeds and eject others.

(6) Both networks used neutral language to represent the two events however there is a focus on the capitol rioters.

(7) As for words of violence, both used enthusiastic words to indicate rejection of violence and the behavior of the rioters in general and in particular in such a representative symbolic place.

(8) From a legal point of view, both events are illegal for breaking the law and attacking the highest institution responsible for asserting laws in the country and both are happing for the first time. The goal for both events is the same which is defending false target for unwanted president.

In each of the examples mentioned in the analysis part the writer's aim was facilitative, aimed at drawing out the reader and encouraging him or her to form positive attitude towards his own country and condemn what rioters did. This is 
The ESCCB and the ACR: Is It the Same Fight? Reading on Others' Ideology: A

Pragmatic Analysis of the CNN and BBC Websites

through explicit statements or implicit meaning through the speech acts used. This interpretation depends, however, not just on lexical devices, but even through the context drawn to the reader. There is evidence, that, uttered linguistic devices, in boosting the force of speech acts, express positive feelings towards Biden and rejection and blaming towards the rioters and violence.

\section{Conclusions and Recommendations}

The speech act theory as a framework in analyzing media reports about both events enabled us to explore the language use of media context. This fact is confirmed by the speech acts that are manifested through the analysis. The ability to understand the hidden message of an utterance is essential in pragmatic analysis. By understanding pragmatics and speech acts, one can get a clearer understanding of the utterances. Knowing words is not enough, but knowing how to use words to carry out actions is more important. Language as a vehicle for social activity can be used to tell things that are ignored. Media coverage played a crucial role in the rapid events of the Arab Spring, which were framed and understood by audiences worldwide. This study investigated how the two networks with different political ideologies reported the same event displaying the same attitudes through the use of language. The findings suggest that any utterance is a goal-oriented speech act, and no illocutionary force could exist without its perlocutionary counterpart effect. Their reports did not affect the political discourse though affecting the general viewpoints and empowering the individuals. More studies may be conducted to explore the readers themselves and the media's effects on them and how the newsreaders interpret the reported events. Indeed, further research can determine if writers represent what readers need and want or what they really want them to know. Within the speeches of one culture, we can find differences depending on the circumstances that surround both events. The present study opens horizons for further future CDA research on the media coverage of news. Further, it would be helpful to expand this investigation to include other media tools like images and videos with the MAXQDA program. There is also a need for further study to investigate the content and quality of the texts in a more systematic way. More studies are required to highlight the recognition of illocutionary forces and Perlocutionary acts in these articles of readers of these websites through their comments and feedback on the sites.

\section{References:}

Abba T. \& Nasiru, M. (2015). "Speech Act Analysis of Daily Trust and The Nation Newspapers Headline Reports on "Boko Haram" Attacks" Journal of Communication and Culture, 6(1),. 63-72. 
Allott, N. (2010). Key Terms in Pragmatics. Continuum International Publishing Group.

Barkho, L. (2008). The Discursive and Social Power of News Discourse: The case of Aljazeera in comparison and parallel with the BBC and CNN.

Beard, A. (2000). The Language of Politics. London: Rutledge.

Billig, M., Condor, S., Edwards, D., Gane, M., Middleton, D., \& Radley, A. (1988). Ideological Dilemmas: A Social Psychology of Everyday Thinking. Thousand Oaks, CA, US: Sage Publications, Inc.

Brewer, R. (2006). National interest frames and public opinion about world affairs. The Harvard International Journal of Press/Politics, 11 (4), 89102.

Carvalho, A (2000), Discourse analysis and media texts: a critical reading of analytical tools, Universidade do Minho, Centro de Estudos de Comunicação e Sociedad, Braga.

Chiluwa, I. (2007) "News Headlines as Pragmatic Strategy in Nigerian Press Discourse." The International Journal of Language, Society and Culture, 27, 63-71.

Conboy,M. (2007) The Language of News. New York: Routledge.

Devereux, E (2007) Media Studies: Key Issues and Debates. SAGE Publications.

Dor, D. (2003) “On Newspaper Headlines as Relevance Optimizers.” Journal of Pragmatics,35, pp.695.-721.

Duanprakhon, P. (2012) "Critical Discourse Analysis of News Headlines: A Case of Youth Crime in Thailand.' Unpblished M. A. Thesis National Institute of Development Adminstration

Fairclough, N. (1995). Media discourse. London, England.

Fairclough, N., (2003), Analyzing Discourse: Textual Analysis for Social Research, London: Routledge

Fowler, R. (1991). Language in the News: Discourse and Ideology in the Press. London: Routledge

Fromkin, V., Rodman, R., \& Hyams, N. (2003). An introduction to language. Boston: Thomson/Heinle.

Ghannam. N (2010) newspaper ideology: a critical discourse analysis of an event published in six Lebanese newspapers. A Research Report submitted to the Faculty of Humanities in partial fulfilment of the requirements for the degree of Master of Arts in Translation University of the Witwatersrand, South Africa 
The ESCCB and the ACR: Is It the Same Fight? Reading on Others' Ideology: A Pragmatic Analysis of the CNN and BBC Websites

Glover, K (2011) Analysis of CNN and The Fox News Networks' framing of the Muslim Brotherhood during the Egyptian revolution in 2011. The Elon Journal of Undergraduate Research in Communications, 2(2), Fall 2011

Grice, P. (1989). Studies in the Way of Words, Cambridge, MA: Harvard University Press

Halliday, M \& Hasan, R. (1970). Cohesion in English. London: Longman. Halliday, M. (1985). An Introduction to Functional Grammar,1st ed. London: Edward Arnold.

Horn, L. \& Kecskes, I. (2013). Pragmatics, Discourse, and cognition. Yale University.

Ilyas, S, \& Khushi, Q, (2012). Facebook status updates: a speech act analysis. Acad. Res. Int. 3 (2).

Javad, S. \& Mahmood, R. (2011). A critical Discourse Analysis of The News Headlines of Budget of Pakistan FY 2011-2012 Inter Disciplinary Journal of Contemporary Reserach in Business 3(5).

Kempson, R (1986). Semantic Theory. London: Cambridge University Press. Kuypers,J (2002) Press Bias and Politics: : How the Media Frame

Controversial Issues. WESTPORT, Praeger, London.

Leech, G. (1983) Principles of Pragmatics. London: Longman

Mahammad, A; Rashid, R; Yunus, K; Abdul Rahman, S; Darus, S \& Musa, R (2018). Speech acts in the Facebook status updates posted by an apostate. Int. J. Engl. Ling. 8 (4), 226-231.

Macdonald, M. (2003). Exploring media discourse. London: Arnold.

Matheson, M. (2005). Media discourses: analyzing media in texts. England:

Open University Press.

Mey, L. (2001) Pragmatics: An Introduction. Oxford: Blakwell Publisher.

Muhammed, M. (2005) "A Pragmatic Analysis of Selected English Political Newspaper Headlines.” Unpublished M.A. Thesis University of Baghdad, Iraq.

Mumby, D. (2009) Ideology \& the social construction of meaning: A communication perspective. Communication Quarterly, 37(4),. 291-304 Novianto, W (2015) Contrastive rhetoric analysis on the Syrian conflict in CNN and Al-Jazeera selected news. Undergraduate thesis, Universitas Islam Negeri Maulana Malik Ibrahim. 
The ESCCB and the ACR: Is It the Same Fight? Reading on Others' Ideology: A

Pragmatic Analysis of the CNN and BBC Websites

Prakash, A. \& Dhawan, A. (2017). "Linguistic Divergences in Newspaper Headlines." International Journal of Engineering Technology Science and Rresearch, 4(7),.858-864.

Reah, D. (1998). The Language of Newspaper. London: Rutledge.

Reah, D. (2002). The language of newspapers. 2nd edition. London, Routledge.

Roya, M \& Mahadi, T. (2017). The Rhetoric of Persian News Headlines: A Case Study of Euronews. International Journal of Applied Linguistics and English Literature, 6(2),.36-45.

Rustam, R. (2013). Pragmatic Analysis of CNN Headlines Representing Pakistan. Unpublished Ph.D. Dissertation, University of Azad Jammu and Kashmir, Muzaffarabad, Pakistan.

Sauerland, U. \& Schumacher, P. (2015). Pragmatics: Theory and Experiment

Growing Together. Linguistische Berichte, 245, 3-24.

Searle, J. (1969). Speech acts: an essay in the philosophy of language.

Cambridge, UK: Cambridge University Press.

Searle, R. (1979). "A Taxonomy of Illocutionary Acts", in Searle J. R. (ed.) Expression and Meaning: Studies in the Theory of Speech Acts, Cambridge University Press. 1-29.

Siposova, A. (2011). Headlines and Subheadlines: Tense, Modality and Register Based on Discourse Analysis of The British Tobloid the Sun. Unpublished Ph.D. Dissertation, Masaryk University, Berno, Czech Republic.

Song, L. (2010). The Role of Context in Discourse Analysis. Journal of

Language Teaching and Research, 1(6),. 876-879

Tauchid, A, \& Rukmini, D, (2016). The performance of expressive speech acts as found on Wayne Rooney's Facebook. English educational journal 6 (1).

Van Dijk, A. (1977). Text and Context: Explorations in the Semantics and Pragmatics of Discourse. London; Longman.

Van Dijk, A. (1985a). Discourse and Communication: New Approaches to the Analysis of Mass Media Discourse and Communication. Berlin: de Gruyter.

Van Dijk, A. (1988). News as Discourse. New York: Erlbaum.

Van Dijk, A. (2007). Ideology and discourse analysis London: Sage.

Watson, R. \& Hill A. (1993). A Dictionary of Communication and Media Studies, London. 
The ESCCB and the ACR: Is It the Same Fight? Reading on Others' Ideology: A Pragmatic Analysis of the CNN and BBC Websites

Wodak, R (2007). Language, Power and Ideology. Amsterdam: John Benjamins.

Yule, G. (1996). Pragmatics. Oxford University Press. New York

Yuwartik. Y \& Nurhayati , D (2016). An Analysis of Speech Acts in Dialogue of the Novel "The Black Cat". Indonesian Journal of Language Teaching and Linguistics, 1(1):67 


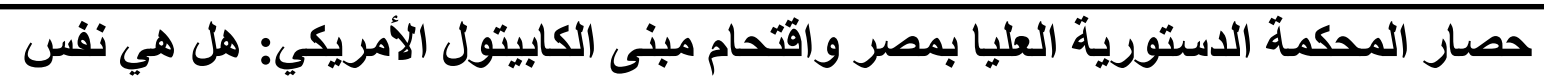

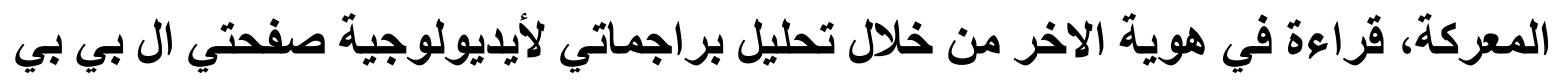
سي وال سي ان ان في تناول الحدثين

$$
\text { قسم اللغة الإنجليزية أحمد على الهمثرية التربية }
$$

alhamshary@edu.dmu.edu.eg

المستخلص:

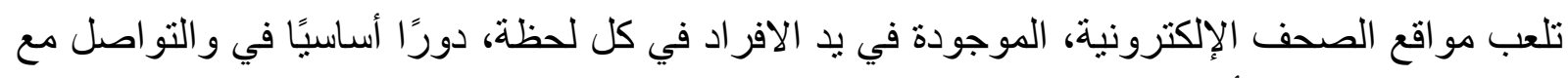

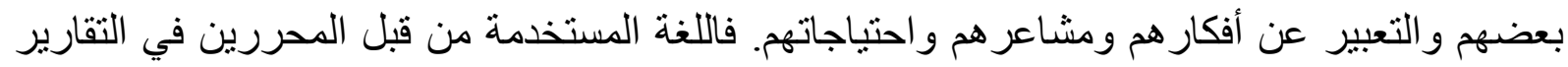

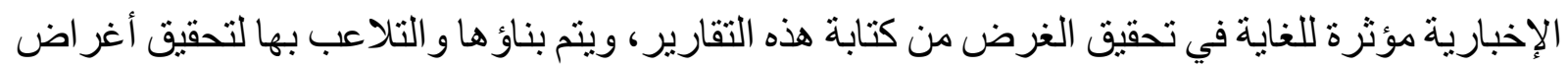

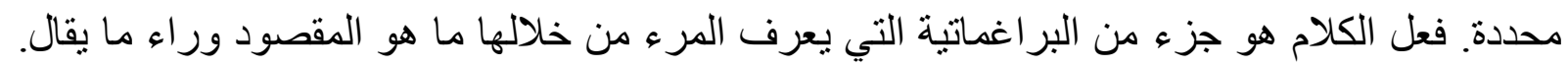

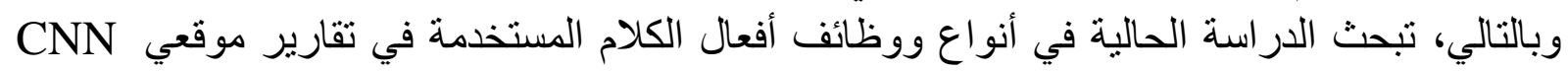

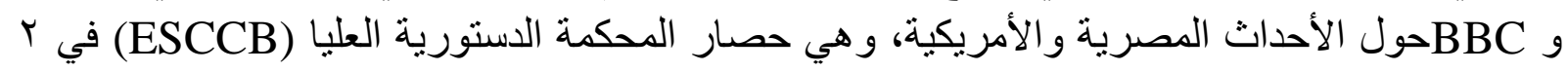

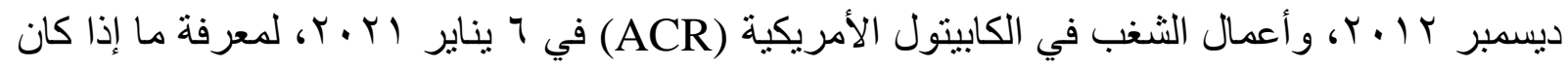
الكتاب يمثلون أيديولوجيتهم الاجتماعية في تغطية كلا الحدثين. تطبق الدراسة الحالية نظرية فعل الكلام

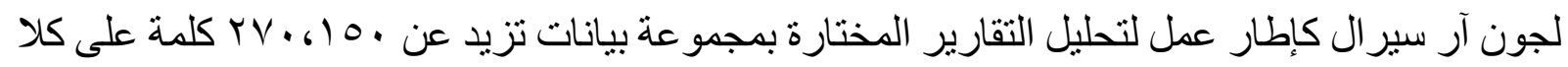

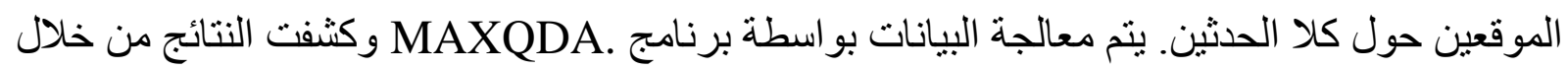
النسب المئوية لأفعال الكلام المستخدمة وانواعها أن كتّاب الموقعين ليسوا منحازين لقضية الحئ الحصار و الثخب، بل هم يدافعون عن موقف سلطة القانون.

CNN- BBC -MAXQDA الكلمات الدالة: تحليل بر اجماتي - الأيديولوجية ـ أفعال الكلام - برنامج 